

\section{Un análisis mitologista de la construcción de la naturaleza desde la intervención artística de espacios naturales}

Javier Guillermo Merchán-Basabe

Resumen
Por medio del esquema mitológico de la Redención,
este trabajo propone tres instancias dentro de la
construcción de la idea de Naturaleza en las socieda-
des industrializadas (Pródiga, Catastrófica y Apoca-
líptica). Dichas instancias no solo implican a la con-
cepción Naturaleza, sino su tratamiento concreto en
la intervención artística de espacios naturales.
Palabras Clave: Naturaleza, Arte, Espacio Natural,
Dominio, Redención.


The idea of Nature: a mythologist analysis of its construction from the perspective of artistic intervention of natural spaces

\section{Summary}

Through the mythological scheme of redemption, this paper proposes three different instances within the construction of the idea of Nature amidst industrialized societies (Prodigal, Catastrophic and Apocalyptic). Such instances entail not only the very concept of nature, but also its concrete treatment through artistic intervention of natural spaces.

Key words: Nature, Art, Natural Space, Domain, Redemption.

Uma análise mitologista da construção da natureza desde a intervenção artística de espaços naturais

\section{Resumo}

Por meio do esquema mitológico da redenção, este trabalho propõe três momentos dentro da construção da ideia da Natureza nas sociedades industrializadas (pródiga, catastrófica e apocalíptica). Estes momentos não somente implicam a concepção da natureza, mas, seu tratamento concreto na intervenção artística de espaços naturais.

Palavras Chave: Natureza, Arte, Espaço Natural, Domínio, Redenção.

\section{La Naturaleza como idea}

¿Qué queda entonces, si todo intento de ser algo Naturaleza se revela falaz y todo intento de apresar o definir Naturaleza interesado, si Naturaleza se convierte en religión e ideología, si falsamente se opone a artificio y azar, si el arte no puede apresar a Naturaleza, y menos aún ser Naturaleza? Bien podríamos afirmar que "la Naturaleza no existe" a condición de no reparar en los mecanismos que determinan la "existencia" de las cosas. (Albelda \& Saborit; 1997, p.53).

\section{El secreto de la naturaleza}

De seguro no hay nada más polisémico que el término "naturaleza". Este se refiere a una totalidad en la que se contienen substancias no creadas: agua, tierra, oro, etc.; especies: animales, insectos, árboles, matorrales, etc.; objetos naturales: icebergs, montañas, volcanes, planetas, la luna, etc.; fuerzas naturales: gravedad, magnetismo, etc.; apariencias de lo natural: el cielo azul, el sol brillante y cálido, el arco iris, la penumbra, etc.; fenómenos naturales: lluvia, viento, nubosidad, nieve, etc.; productos naturales del entorno: canto de los pájaros, el tejido de la araña, el olor de las flores, etc.; entre otras cosas. Polisemia que se amplía en el campo del arte y la estética puesto que el término también denota ciertos contenidos teóricos: mundo físico, orden y disposición de todos los recursos no creados por el hombre, organismo que alberga las especies vegetales, minerales, ecosistemas, medio ambiente, etc.; asociados a diversos referentes visuales: paisaje, jardín, fauna, flora, bosque, desierto, selva, etc.

La amplia gama de significaciones del término "Naturaleza" señala que a ella en sí misma, se le define aunque se le desconoce. Así lo entienden Albelda y Saborit (1997) en "la construcción de la Naturaleza" al postular que a pesar del desconocimiento de la Naturaleza, la tradición occidental tiende a presentar algunas formas generales con las que ella se ha definido desde la antigüedad. En la primera forma se define a un conjunto todos los seres y fenómenos del mundo (Physis) incluido el hombre, esto es, todo lo que existe para la experiencia y la ciencia natural; en otra, la definición es referida generalmente a principios trascendentes al ser vivo, al factor esencial de la vida (origo rerum) y no tanto a los fenómenos; en otra más, la definición se refiere a lo no producido por el hombre y lo intocado por él. De esa forma, Albelda y Saborit sostienen que las definiciones corresponderían a elementos de una construcción social de la Naturaleza en tanto se complementan.

Los hombres "desconocen la Naturaleza” pero requieren de ella, viven en y de ella, por eso, "la construyen" de acuerdo con las posibilidades de aprovecharla, la edifican desde la necesidad de subsistir. Toda definición de la Naturaleza corresponde a una construcción social, no es un conocimiento objetivo. La Naturaleza como constructo, va más allá de las definiciones fundadas en filosofías de la identificación o de la distinción entre sujeto-objeto, se asimila a una idea ${ }^{1}$ o a una representación colectiva de la totalidad natural originaria personificada como un ser contenedor de unos misterios que el hombre quiere develar² y usar en su beneficio.

\footnotetext{
${ }^{1}$ Una idea como representación, es el resultado de una actividad cognoscente. Aquí es una representación social-histórica de la relación hombre-mundo, una construcción a nivel intersubjetivo. Aquí se prefiere usar el término "idea” en vez del término "concepto”, pues un concepto se supone que deriva de un conocimiento objetivo, es decir, es resultado de una descripción y análisis que produce niveles definitorios esenciales de la cosa, una abstracción que se formula y resulta estable y que en el caso de la Naturaleza aquí referida no aplica.

${ }^{2}$ El término "develar" hace referencia al papel de la ciencia y el mito; aunque en diferente grado, la ciencia y el mito son una búsqueda de desciframiento de los secretos de la Naturaleza, ambas quieren dar razón a los fenómenos por un lado o al orden divino por el otro y explican en cierto grado, algo "más" sobre el orden del universo, descubren para el hombre la complejidad de lo que era oculto.
} 
Si se ahonda en el planteamiento que fundamenta una necesidad humana de conocer la Naturaleza para subsistir, ella pasa a ser aquello que posee un gran secreto: un ente, un ser en-sí que oculta el principio de los fenómenos, el cual puede ser usado en beneficio humano. Como ente que esconde un secreto, está en riesgo que éste que le sea arrancado. La posibilidad de develamiento aparece en la medida en que el hombre se afianza en determinar principios y leyes fundamentales para modificar sus condiciones de subsistencia. De la Naturaleza como de lo oculto, no se tiene sino una idea limitada, una representación o una apariencia construida acorde a un grado de develamiento del secreto.

La idea de Naturaleza no es una construcción conceptual objetiva y atemporal, sino histórica y cultural; la representación de la Naturaleza cambia de acuerdo a las necesidades humanas en la historia, se constituye dentro del campo virtual público o de producción simbólica de las sociedades. Toda sociedad da cuenta de su grado de conocimiento y acción sobre la Naturaleza, al interior de ese campo, dentro de una cosmovisión que cuenta con rituales y mitos. Allí las sociedades cohesionan y dan sentido al pensamiento de la Naturaleza y a las acciones grupales sobre el territorio y se sustenta el ánimo por cubrir necesidades presentes y por realizar esperanzas o promesas futuras.

\section{Prometeo y Orfeo}

De poder realizarse una historia de la construcción de la idea de Naturaleza -como producto cultural- esta estaría sujeta a la necesidad del hombre por descifrar el gran secreto y traducirlo en símbolos y leyes (mitos y teorías) para poder subsistir. Pierre Hadot, (2004), en "El Velo de Isis: ensayo sobre la historia de la idea de Naturaleza" ${ }^{3}$, recrea este proceso de ocultación y develamiento de la Naturaleza. Según Hadot, a finales de la antigüedad, la Artemisa de Éfeso (hija de Zeus y hermana de Apolo) fue identificada con la egipcia Isis (esposa de Osiris y la madre de Horus), la personificación de la Naturaleza o la madre primigenia. La identificación desempeñaría un importante papel en el pensamiento occidental puesto que fundamentaría imaginarios de la idea de Naturaleza originaria como un secreto a develar. Isis, una representación de la feminidad pródiga, semidesnuda y atiborrada de glándulas mamarias, se escondía tras su velo; por medio de un texto antiguo que Plutarco atribuye los cultos antiguos a Isis y que dice: "Yo soy lo que fue, lo que es y lo que será, ningún mortal ha levantado mi velo" (p. 29) ${ }^{4}$ Hadot sugiere una implacable ansiedad humana por correr el velo de Isis, de forma que el hombre resulta enfrentado a la Naturaleza gracias al ansia de arrancarle sus secretos.

La Naturaleza resulta un constructo determinado por la posibilidad humana de develarla para usarla. Por medio de la imagen de una diosa-naturaleza tras un velo, Hadot, siguiendo a Heráclito, postula que "la Naturaleza gusta de esconderse" (p. 48)5; el constante des-conocimiento de los principios de los fenómenos y sus dinámicas en general, la asimila a la tenedora de un "gran secreto" acorde a la ignorancia humana. En la antigüedad, el gran secreto, lo desconocido, estaba en posesión de los dioses, pero luego, gracias a una posterior personificación de la Naturaleza, ella pasó a detentarlo, con-

\footnotetext{
${ }^{3}$ Hadot, Pierre. "Le voiled' Isis. Essai sur l'histoire de l'idée de Nature". Ed. Gallimard. París. 2004.

${ }^{4}$ Ibíd. Texto original: "Je suis ce que fut, ce qui est et ce qui será. Aucun mortel n’a soulevé mon voile.” Traducción por el autor.

${ }^{5}$ Ibíd. Aforismo 123 de Heráclito citado por Hadot "la Nature aime à se cacher".
}

virtiéndose en guardián receloso de unas leyes que el hombre podía conocer (p. 44) ${ }^{6}$. De esa forma, Hadot, interpretando la sentencia de Heráclito, sugiere que el gran misterio, el secreto de la Naturaleza, no podría ser más que el acto de develarla (p. 105-106), el acto humano de conocerla.

Para Hadot, el gran secreto que detenta la Naturaleza es el quid de los principios universales y de los fenómenos temporalmente inexplicables; el hombre debe darles razón para subsistir, debe robarle los secretos a la Naturaleza y salir de los fenómenos, encontrar mecanismos del orden sensible para ponerlos a su beneficio. En este sentido, se puede anotar que desde la antigüedad, la mística y la física (el estudio de la Naturaleza) se perfilaron como actitudes de develamiento de una Naturaleza velada. Así, para Hadot la necesidad humana de subsistir ha desarrollado paralelamente, dos actitudes de develamiento o perspectivas de revelación de la idea de Naturaleza contrapuestas: la órfica y la prometeica (p. 106).

Hadot señala que en el develamiento y uso de la $\mathrm{Na}$ turaleza, la actitud misticista de Orfeo, hijo de Apolo, personaje asociado a la música y la poesía siempre rodeado de liras y animales, se contrapone la actitud de físico propia de Prometeo, el titán preocupado del bienestar de los mortales frente a la adversidad del medio natural, perspicaz y capaz de engañar al mismo Zeus, asociado a la ciencia y la técnica. La perspectiva órfica de develamiento, en la que la Naturaleza es concebida a semejanza del pensamiento del poeta y el artista, es responsable de levantar el velo de los misterios, de acercar al hombre a secretos y a maravillas a la par del arte, pues en ella "la ocultación de la Naturaleza no es vista como una resistencia a superar, sino como un misterio en el que el hombre puede poco a poco ser iniciado" (p. 106) ${ }^{7}$. Por otro lado, la perspectiva prometeica, en la que se afirma la determinación de los seres humanos para romper los velos, es la generadora de la confianza de ser amos y poseedores de la ley, en ella "el hombre buscará por medio de la técnica afirmar su poder, su dominación, sus derechos sobre la Naturaleza" (p. 106) ${ }^{8}$.

Según Hadot, "con la oposición entre una actitud órfica y una prometeica no se ha querido oponer una buena y una mala actitud, simplemente se quiere llamar la atención sobre dos orientaciones que pueden producirse en las relaciones del hombre con la Naturaleza, dos orientaciones complementarias la una y la otra y que no se excluyen necesariamente" (p. 111) Hadot señala que hay dos maneras de cuestionar o de procesar jurídicamente la Naturaleza para que ella "confiese" sus secretos; sin embargo, es en la entremezcla de estas dos maneras donde se genera la idea de Naturaleza, tal como se deduce de

${ }^{6}$ Véase también el apartado llamado "la personnification de la nature" y el capítulo 3 "secrets des dieux et secrets de la nature".

${ }^{7}$ Texto original: "1' occultation de la Nature ne sera pas perçue comme une résistance qu 'il faut vaincre, mais comme un mystère auquel l'homme peut être peu à peu initié."

${ }^{8}$ Texto original: " 1 ' hommecherchera, par la technique, à affirmer son pouvoir, sa domination, ses droit sur la Nature". Ibíd.

${ }^{9}$ Texto original: "en opposant attitude prométhéenne et attitude orphique, je $n$ ' ai pas voulu opposer une bonne et une mauvais attitude, $j$ ' ai voulu simplement, par ce recours aux mythes grecs, attirer l'attention sur deux orientation qui peuvent se manifester dans le rapport de l'homme avec la nature, deux orientations qui sont aussi nécessaires l'une que l'autre, qui ne s'excluent pas nécessairement et souvent réunis dans le même personnage" Ibíd. 
su concepto de "física de la contemplación" [physique de contemplation], que como las palabras lo sugieren, designa una hibridación entre la perspectiva prometeica y la órfica (p. 50) de construcción de la idea de Naturaleza, presente, por ejemplo, en el Tímeo de Platón.

\section{Mitificación / desmitificación}

Aunque en el conocimiento de la Naturaleza, desde la Antigüedad hasta el Renacimiento predominó la perspectiva órfica, el culto a la exégesis, la metáfora, la alegoría a los principios y el aforismo, y desde la Reforma predominó la perspectiva prometeica, los mecanismos de integración, el método experimental y el enunciado categórico ${ }^{10}$, ambas perspectivas de develamiento se entrecruzan y juntas descifran el gran secreto (p.109). El conocimiento en tanto desciframiento no es exclusivo de una perspectiva; los científicos no eliminan a los poetas, además, estos saben cómo crear con los teorizadores, la ciencia construye la Naturaleza como un fenómeno pero el poeta la construye celebrando el misterio que sugiere sus principios. La perspectiva prometeica no participa principalmente del conocimiento de la Naturaleza, busca sus mecanismos constituyéndola a partir de la suma de las partes; igualmente la perspectiva órfica, que apegada al éxtasis mental generada del despliegue del $\mathrm{mito}^{11}$, exige de la Naturaleza lo que puede decir la exégesis.

La idea descifrada de la Naturaleza se genera de la relación de las perspectivas órfica y prometeica, los cambios en la idea misma dan cuenta de una alteración de la actitud humana de develamiento o de un proceso de mitificación y desmitificación. Esto sugiere que en "la época de industrialización de las sociedades" la idea de Naturaleza no estaría menos mitificada que en la edad antigua o entre los primitivos, aunque obedezca a una desmitificación creciente. Habitualmente, la idea de Naturaleza de las sociedades industrializadas es asimilada al producto del totalitarismo de la ciencia y la racionalidad, producto caracterizado por Hadot dentro del desarrollo de la perspectiva prometeica de develamiento; sin embargo, la idea de naturaleza no deja fundarse en un mundo simbólico ${ }^{12}$. A pesar de la expansión desmitificadora del pensamiento tecno-científico moderno, en éste germinan concepciones órficas o reintroducciones de explicaciones mágicas lo que produce una mezcla de ámbitos mítico-científicos en la concepción y relación con la Naturaleza que adquieren carácter narrativo. Hadot utiliza como ejemplos de esta hibridación y narratividad en el develamiento moderno de la Naturaleza, al pensamiento de Rousseau, también al de Novalis, Goethe y Schiller, cargados de una retórica teológica y mística.

Se entiende que en textos y teorías de ciencia natural, biología, ingeniería y disciplinas con un fuerte corte "cientificista", reaparecen planteadas las necesidades humanas frente a la Naturaleza como viejos mitos con su característico vigor cosmogónico, esperanzador y profético. El hecho de que muchas voces, representaciones e imágenes modernas converjan hacia un mismo tópico, puede interpretarse como neo-mito, siempre que la interpretación permita entrever estructuras matemáticas o narrativas, explicaciones complementarias a teorías y finalidades prácticas. Los neo-mitos no tienen que implantar divinidades, ni son arcaísmos, espiritualizan ideas y teorías, es decir, le dan un sentido vívido a la explicación racional, la cargan de significación-emotividad y la transfiguran en relato épico (Morin, 1986, p. 157).

La desmitificación de la idea de Naturaleza, propia de la época de industrialización de las sociedades occidentales, vendría potenciada por un nuevo proceso de mitificación. Distintos neo-mitos se asocian a la valoración que vino a adquirir la Naturaleza por parte de escritores románticos, naturalistas y biólogos, que apreciaban los espacios naturales "no alterados" como objeto de estudio y que inspiró desde el siglo XIX una constante renovación de la Naturaleza en el arte en términos de su percepción frente a la realización humana (p.27). Ciertos neo-mitos o mitos modernos emergieron en un momento en el que la idea de Naturaleza era fundamentalmente asociada al conocimiento técnico-científico y al trato utilitario de los espacios naturales y se perpetuaron en un momento de escepticismo hacia toda mitología (p. 11).

La perpetuación o el crecimiento de los neo-mitos, tiene que ver con la desmitificación/mitificación de la Naturaleza producida por la transición a un modelo de vida urbano-industrial; relatos sobre un

\footnotetext{
${ }^{10}$ Ibíd. La idea del paso de una perspectiva órfica a una prometeica de revelación de los secretos de la Naturaleza se desarrolla en Pg. 51 y siguientes, en el apartado titulado: "les secrets de la natureau Moyen âge et dans les temps modernes"; por otra parte la idea del cambio de formas, simbolismos y usos del lenguaje en 108 y siguientes, en el apartado titulado: "Promete et Orphée".

${ }^{11}$ Aquí el mito es un equivalente de la búsqueda de la "verdad" tanto como la teoría, no es un contrario sino un complemento de ella.

12 La expresión "renovación del mundo simbólico" hace referencia a los cambios de mitologías de la naturaleza generadas de la renovación del pensamiento propio de la cultura moderna, por ejemplo, el surgimiento de nuevas mitologías como la del estado/ nación, el mesianismo técnicocientífico, etc. A este respecto vale la pena mencionar a Morin (1986) y su texto "El conocimiento del conocimiento", en el que desarrolla a fondo la hipótesis de que el pensamiento técnico-científico- racional, todavía hoy, se ve parasitado por el pensamiento mítico.
} 
estado originario que se vería afectado por la tecnificación de las sociedades, el cambio de actitud humana frente a la naturaleza con respecto a la del hombre primitivo y otras secuelas propias de la catástrofe ecológica permiten suponer al menos dos instancias de la construcción de la Naturaleza: una marcada por lo originario, la pureza y lo aprovechable y otra marcada por la pérdida, por lo mancillado, por la culpa.

\section{Pecado: naturaleza en una instancia pródiga}

Los artistas americanos de la segunda mitad del siglo XIX han de tratar lo cotidiano, lo cercano, lo ordinario americano. A su modo de ver, el contacto con la Naturaleza debe estar disociado del arte, de la estética, en beneficio -entre otros- de los inventores y los medios técnicos de acceso a la Naturaleza. En esa perspectiva, América la reconocemos con frecuencia relacionada con los grandes espacios, con la Naturaleza salvaje, con las megalópolis, la expansión por repetición, la conquista del espacio. (Mottet, 2006, p. 159).

\section{Arte y neo-mitos de la naturaleza pródiga}

De acuerdo con lo dicho se puede plantear una instancia "pródiga" de la construcción de la Naturaleza, producto de una mitología del dominio y el antropocentrismo. En ella sobresalen referencias al pecado, a un estado inicial de la Naturaleza y el ansia humana por aprovecharla. Según Dieges (2005), en su texto "el mito moderno de la naturaleza intocada", las sociedades pre-industrializadas reemplazaron a los mitos bioantropomórficos, en los que el hombre es y está en Naturaleza, por otros neo-mitos, generados por la adopción de nuevas simbologías como el progreso, la confianza en la técnica u otros sinónimos de esfuerzo, expansión y conquista ${ }^{13}$. Ese proceso de mitificación/desmitificación se ejemplifica trayendo a colación el caso de la expansión urbana sobre algunas zonas del oeste americano. Desde la segunda mitad de siglo XIX, se revitalizaría dentro de la sociedad norteamericana, imagen de una sociedad prometeica que abocaba por la ciencia y la tecnificación, todo un mundo simbólico en el que tendrían cabida mitologías de la Naturaleza-prodiga que aunque hacían alusión a un contexto específico, no se correspondían con la realidad vigente sino con anhelos propios del colono de proyectarse sobre el medio natural para ponerlo a su servicio.

Mitos modernos asociables a una instancia de Naturaleza Pródiga que tendrían repercusiones prácticas en Norteamérica, en la creación de parques, jardines, reservas, paisajes naturales mercantilmente aislados. Dieges da muestras de esta repercusión

La noción de mito naturalista de la naturaleza intocada, del mundo salvaje, se refiere a una representación simbólica por la cual existirian áreas naturales intocadas e intocables por el hombre, presentando componentes en un estado "puro", incluso anterior al aparecimiento del hombre. Ese mito supone la incompatibilidad entre las acciones de los diversos grupos humanos y la conservación de la naturaleza. De ese modo, el hombre sería un destructor del mundo natural y por lo tanto, debería ser mantenido separado de las áreas naturales que necesitarian de una "protección total". (2005, p. 27).

Los neo-mitos señalan carencias reales, la necesidad colectiva de realización de una utopía con respecto del medio natural y el caso americano es fiel testimonio de ello. El mito del buen salvaje, un tópico clásico de la filosofía, el arte y la literatura, es casi un referente obligado a los relatos sobre los primeros encuentros entre las sociedades nativo-americanas y las europeas. Refleja un anhelo por presentar una instancia anterior del hombre, carente de maldad para con el medio natural, perdida durante el proceso de industrialización de las sociedades. Por su parte, el mito de la naturaleza salvaje o "wilderness" proclamaba la idea generalizada de una pureza primigenia de los entornos a las urbes que en el siglo XIX ya era inexistente; salvajes se denominaban a las grandes zonas ya no habitadas por aborígenes, principalmente debido al exterminio y la expansión de la frontera hacia el oeste. De la misma manera, la unión de los neo-mitos anteriores, la nueva Arcadia, paralelizada a la América nativa, refiere tanto al hombre primero, al hombre noble, sin jerarquías, sin pudor artificial, como al nuevo Edén, al lugar apto para el goce humano.

Al respecto de estos neo-mitos asociables a una Naturaleza Pródiga, encarnados en voces, representaciones e imágenes, propias de las necesidades de una sociedad en camino a la industrialización, el jefe Sioux, Standing Bear, sobreviviente a la expansión hacia el oeste decía:

\footnotetext{
${ }^{13}$ Ibíd. Esta idea de una conquista de la Naturaleza es desarrollada por Dieges (2005) entre las páginas, 11, 13 y 43; por otro lado la idea de un cambio de mitologías dado en el paso del mundo antiguo al moderno, de la página 27 a la 33 el apartado titulado: "Los mitos bioantropomórficos, los neomitos y el mundo natural".
} 
Nosotros no consideramos salvajes (wild) las vastas planicies abiertas, los maravillosos montes ondulados, los torrentes sinuosos. Para el hombre blanco la naturaleza era salvaje, pero para nosotros ella era domesticada. La tierra no tenía cercas y estaba llena de bendiciones del Gran Misterio" (Citado por Dieges, 2005, p. 13).

El imaginario de zonas vírgenes o intocadas sumado a la expansión de las urbes, el crecimiento de zonas agrícolas y la industrialización llenó de contenidos a neo-mitos que solo tenían significación para los colonizadores; todo ello revitalizaría en Norteamérica la evocación de cierta nobleza humana en el respeto por el entorno, la simbolización de una posible armonía con la Naturaleza benefactora.

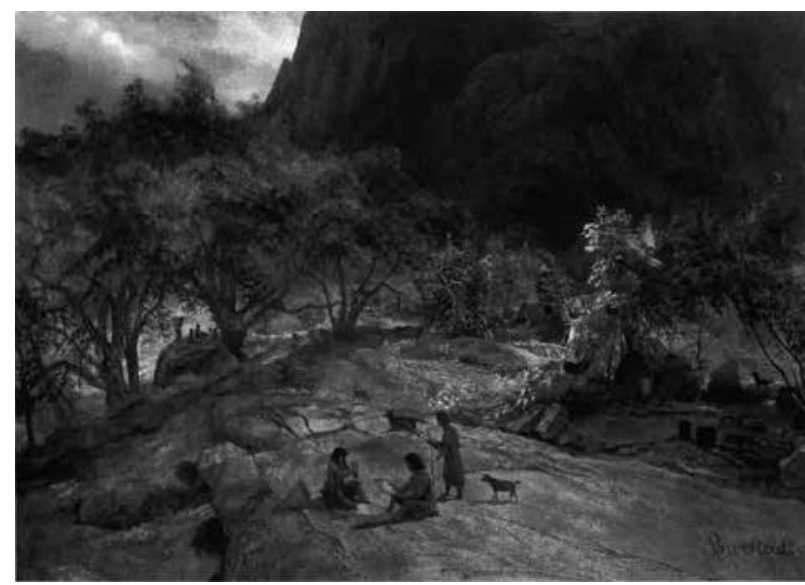

Figura 1. Bierstadt, A. IndianEncampment Yosemite Valley, Ca 1872.

Los neo-mitos de la naturaleza pródiga tienen incidencia en "el arte". Un gran ejemplo de dicha incidencia está en la pintura y el cine que podría catalogarse como "western". En este caso vale la pena traer a colación la obra de Albert Bierstadt Indian Encampment Yosemite (fig.1), un pintor germano- estadounidense conocido gracias a sus paisajes del oeste americano y por la representación de la vida de los nativos. Bierstadt fue parte de la escuela del río Hudson, que no fue precisamente una institución o movimiento pro-naturalista, sino más bien un grupo informal de pintores paisajistas con ideas afines. El estilo de la escuela del río Hudson, estaba fuertemente involucrado con el estudio cuidadoso de la luminosidad, sobre todo en la pintura romántica. Esta pintura bañada en un tono dorado, parece sugerir la nostalgia de una época anterior, específicamente, un tiempo en que los nativos americanos "vivían" en armonía con la Naturaleza; el color dorado pareciera asimilar la obra a la tradición europea en la que se nota la variedad de escenas de Arcadia, pero en una versión americana que debe asumir la particular complejidad de referirse a dos maneras de ser y pensar la relación del hombre con el entorno.

El campamento de "indios" en Yosemite pareciera mostrar la naturalidad o la ausencia de técnicas y la aparente nobleza de los aborígenes frente al medio natural antes de cualquier contacto con los europeos; como si señalara una fantasía pseudo-histórica o una reconstrucción neo- mítica de la Naturaleza y de la vida de los nativos por parte del hombre blanco, esta pintura, sin duda, proporcionaba al público una imagen que quería retener, sobre todo durante los años en los que sistemáticamente los indios habían sido exterminados y sus tierras eran transformadas vertiginosamente.

Los neo-mitos sugeridos en el trabajo de Bierstadt, señalan la incidencia de una instancia pródiga de la idea de Naturaleza en prácticas artísticas, en especial, esos neo-mitos repercutirían en usos estéticos del entorno, en el desarrollo del jardín o la arquitectura del paisaje, harían eco de ideales del paraíso y de una pureza primigenia en las primeras leyes ecológicas, en la apreciación y preservación de espacios naturales, lo que conllevaría a la creación de parques y reservas. Por eso la referencia a Bierstadt, su pintura describe el imaginario del hombre blanco de la relación entre los aborígenes y el entorno de Yosemite, al suroeste de Estados Unidos, un lugar donde se establecería el primer sitio protegido o parque natural estatal del planeta, antes que el parque nacional de Yellowstone, lo que paradójicamente implicó, la expulsión de los nativos para preservar la pureza ${ }^{14}$ del sitio.

\section{El sueño de dominio}

El dominio de la naturaleza, así lo enseñan los imperialistas, es el propósito de toda técnica. Pero, ¿quién podría confiar en un maestro que, recurriendo a una palmeta, viera el propósito de la educación en el dominio de los niños por parte de los adultos? ¿No es la educación, ante todo, la organización indispensable de la relación entre las generaciones $y$, por tanto, si se quiere hablar de dominio, el dominio de la relación entre las generaciones y no de los niños? Lo mismo ocurre con la técnica; no es dominio de la naturaleza, sino dominio de la relación entre naturaleza y humanidad. (Benjamín, 1926,citado por Buck-Morss, S.2004, p. 157).

Tal como lo sugiere Arnold (2000) en "La Naturaleza como problema histórico", el conocimiento y trato de la Naturaleza representa un importante problema puesto que se debe encontrar la forma de pensar un proceso de alejamiento y confrontación humana del medio natural agudizado en la modernidad. Al parecer, con respecto de la relación hombre medio natural de la antigüedad y el medioevo, el conocimiento y el trato de la Naturaleza por parte de las sociedades en camino a la industrialización trae un cambio inusitado, evoca una fe ciega en una creciente racionalización y tecnificación que la convertía en un objeto del mundo de las mercancías.

En la construcción de la idea de Naturaleza, la esencia de lo pródigo debe encontrarse en el papel revolucionario de la ciencia y la lucha contra el dogmatismo, en la racionalización del mundo. No es difícil suponer que en el proceso histórico del desarrollo de las sociedades industrializadas, la concepción de la Naturaleza perdió cierto carácter teológico/mágico de antaño asociándose más al reducto abstracto de una dicotomía epistemológica entre sujeto-objeto y a la mercantilización de los recursos naturales, algo que dio rienda suelta a la irreflexión sobre la técnica que sugiere Benjamin en la cita de entrada.

Los procesos que promovían la desmitificación teológica de la idea de Naturaleza estaban sustentados en un ímpetu utilitarista,

\footnotetext{
${ }^{14}$ El peor contrasentido de la operatividad de este neomito de la "pureza" es que el parque Natural Yosemite tiene una afluencia aproximada de dos millones de visitantes anualmente. Véase: http://www.nps.gov/Yose/index.htm
} 
en una nueva mitificación. La Naturaleza Pródiga es el resultado de un sueño de dominio o de explotación del medio natural, de una auto-promesa de felicidad de las sociedades que la encontraban infinitamente dadivosa. Si en las sociedades en camino a la industrialización la Naturaleza es asociable a la abundancia, la riqueza, la pureza, a la fecundidad, el hombre lo será a la realización de esfuerzos, pequeños o grandes, a la consecución de proezas, al ser necesitado de progreso tecnológico, de Prometeo. En este sentido, los neo-mitos sobre el buen salvaje, la Naturaleza intocada, la nueva Arcadia, etc., son complemento perfecto de teorías como la evolucionista y el progreso económico, en tanto sugieren una Naturaleza dadivosa y llena de riquezas y lugares inexplorados que requerían de la mano del hombre, de la ciencia y la técnica para el constante desarrollo social.

La instancia de una Naturaleza Pródiga se sustenta en una auto-promesa de felicidad material, en el anhelo de acumulación de bienes y el aprovechamiento de los recursos. Esta concepción de la felicidad se da en un espacio del imaginario colectivo, en un mundo del "sueño", como el que describe Buck-Morss (2004) en "Mundo soñado y catástrofe: la desaparición de la utopía de las masas de Este y el Oeste". El sueño, la fe y la esperanza compartida por liberales y socialistas como partícipes del mismo proyecto histórico de búsqueda de la felicidad, llevaba a creer que los obstáculos al progreso indefinido y a la acumulación de riqueza indispensable para hacer del mundo un lugar próspero, eran solamente de índole artificial, que ninguna causa u obstáculo natural impedía alcanzar esa meta.

Para las sociedades en camino a la industrialización, el medio para alcanzar el cumplimiento de la promesa, la felicidad, no era otro que el desarrollo de la técnica, una fuerza motora crecientemente impulsada por la ciencia moderna que alteró los términos tradicionales (mágicos) de la relación hombrenaturaleza. La técnica pasa a ser apoyo de un imaginario de conquista propio de la Naturaleza Pródiga o de un proyecto de vida colectiva cuyas motivaciones centrales giran alrededor del afán de lucro y la acumulación sin límites de bienes materiales. Esa fuerza motora, que en su momento contribuyó a liberar a la especie de cargas ancestrales que minimizaban su capacidad para sobrevivir, desató actitudes babélicas que otorgaron al hombre un falaz papel de señoría sobre la Naturaleza.

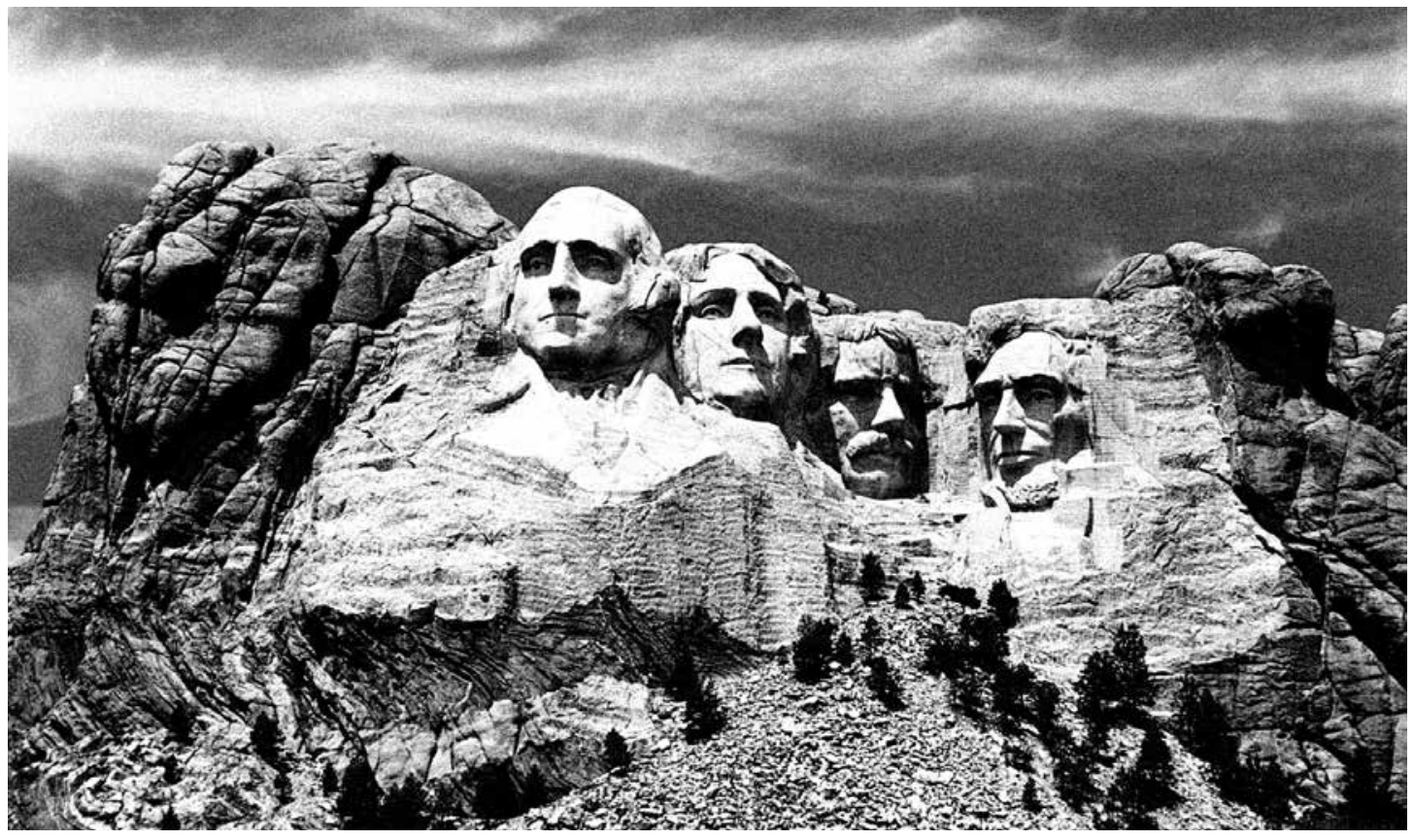

Figura 2. Gutzon B.1927/41, Rushmore National Memorial

La idea de Naturaleza en una instancia Pródiga sustentaría los embates soberbios del impulso prometeico hacia el medio natural, influenciando la intervención artística de espacios naturales. Así por ejemplo, una "sociedad tecnológicamente avanzada" como la sociedad estadounidense del siglo XIX, que construyó una idea de Naturaleza Pródiga acorde a sus fuerzas prometeicas, aceptó sin reparos la realización de una obra como los rostros de los cuatro presidentes de Gutzon Borglum (fig. 2) como la mera exaltación del esfuerzo humano. De dicho monumento, se destacaba el despliegue de medios técnicos para transformar un espacio natural en pro de la construcción de la mayor obra de arte en la Naturaleza o la más 
ambiciosa escultura de montañas ${ }^{15}$ : una talla con las imágenes de G. Washington, T. Jefferson, T. Roosevelt y A. Lincoln de monumentales dimensiones en un espacio de $5,17 \mathrm{~km} 2$ con cuatro rostros, cada uno de 18 metros, aproximadamente.

Acciones prometeicas o de gran envergadura, como las relacionadas a la construcción del monte Rushmore, seguramente ya habían sido realizadas muchas veces en el antiguo Egipto o en Nepal, donde básicamente se esculpían templos en grandes colinas de piedra. Sin embargo, el monumento en cuestión, no perseguía un pacto sagrado con las deidades o las fuerzas de la Naturaleza en un sentido religioso, sino que emulaba, para la sociedad estadounidense del siglo XIX, un triunfo épico del progreso humano dado por la negación de una actitud órfica, primitiva y encantada, en ese sentido representa el producto de un ímpetu avasallador que tenía como derrotero la confianza en la técnica y el sueño de dominio de la Naturaleza Pródiga ${ }^{16}$.

La pertinencia del monumento está en las actitudes soberbias hacia el espacio natural en que fue construido, confronta radicalmente diferencias en el pensamiento y el uso estético de los territorios por parte de sociedades primitivas e industriales. Dos visiones humanas de la Naturaleza y dos actitudes hacia ella incompatibles en el mismo marco espaciotemporal. No sobra decir que este "monumento a la democracia" que conmemora el nacimiento, crecimiento y desarrollo de los Estados Unidos de América, está rodeado de paradojas: fue fijado en un lugar sagrado robado por el estado a la nación Sioux, fue creado por un escultor activo participante del KuKluxKlan, personajes como George Washington decretaron la pena capital a más de 30 líderes Sioux en la pugna por la expansión hacia estos territorios (el mayor record en aplicación de la pena de muerte en el sistema penal estadounidense), etc. por lo demás, es evidente que a muchas personas el monumento les molesta y por ello actualmente se realiza uno muy similar a pocos kilómetros en honor a Crazy Horse ${ }^{17}$.
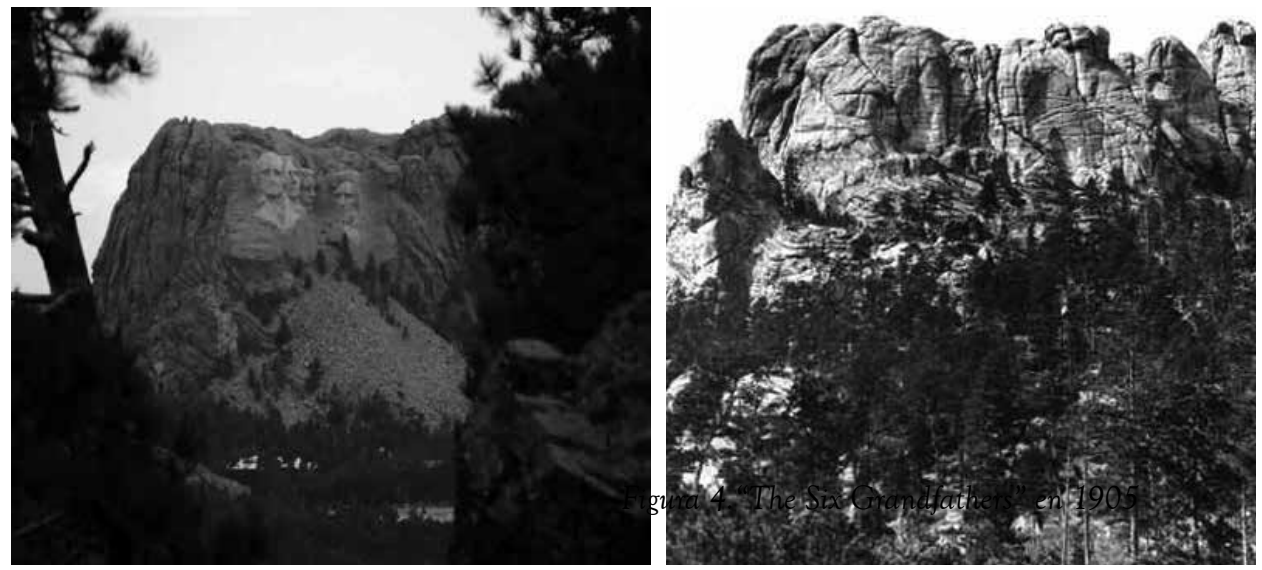

Figura 3.Rushmore National Memorial
La talla (fig. 3) situada en las colinas de Negro (Black Hills), un antiguo territorio sagrado para los indigenas de Dakota del sur, fue realizada en la "montaña de los seis abuelos" (fig. 4), llamada así por los habitantes originarios del lugar, los "Lakota Sioux", quienes a pesar de su resistencia, la vieron convertida en lugar reclamado por la sociedad industrial -posteriormente fue llamada "monte Rushmore" 18 . Antes de semejante intervención, los aborígenes (Lakota Sioux) creían que todo el entorno de la montaña hacia el valle que lo rodea era el centro del mundo y que estaba habitado por espíritus primigenios, por abuelos o sabedores que mueren y cuyos espíritus se convierten en parte del territorio de la comunidad. La montaña de los seis abuelos se erigía sobre el valle como un referente cosmogónico, sin embargo, el descubrimiento de oro en $1874^{19}$ y el establecimiento de minas, sumado a la posterior crecida de buscadores, obligó al gobierno a desplazar a los nativos y a suplantar el uso relacionado con la identidad ancestral del lugar por un uso instrumental orientado por la explotación de la materia bruta de la Naturaleza pródiga.

Aunque la falta de conciencia ambiental y de reflexión del entorno propia del trabajo de Gutzon Borglum era algo menos que tenido en cuenta para la sociedad de su época se puede inferir que su directriz, a la hora de realizar la intervención artística de espacios naturales, estaba respaldada por la ciega confianza en la técnica

\footnotetext{
${ }^{15}$ Borglum ya era conocido por la práctica del tallado de esculturas en montañas enclavadas en lo que aquí se ha llamado espacios naturales. Son famosos por ejemplo, su "Wars of America" en el parque militar de Newark, New Jersey y su monumento a los confederados en Georgia, llamado "Stone mountain. Memorial to the confederacy".

${ }^{16}$ Esta idea de las cuatro efigies de Borglum como símbolo de conquista y dominio de la Naturaleza por medio de la intervención meramente técnica en espacios naturales es esbozada también por Albelda (2002).

${ }^{17}$ El monumento a Crazy Horse es una talla que también se realiza en las colinas de Negro (Black Hills) en honor al legendario guerrero Sioux que nunca se rindió al ejército estadounidense; una acción como contraparte a "los cuatro rostros" de Borglum, que con razón es considerado un monumento al racismo. Sin embargo, la cuestión de realizar una obra como esta en la actualidad sigue siendo materia de amplias discusiones; esta talla sí ha tenido que confrontar las reticencias del pueblo nativo y las preocupaciones de círculos ambientalistas en general, por lo que se ha tenido un cuidadoso manejo en el retiro de material y del entorno. Véase: http://www.crazyhorsememorial.org/. Consultada el 18 de abril de 2010.

${ }^{18}$ Charles E. Rushmoreera un abogado de Nueva York que fue a Dakota del Sur en 1884/5 - que terminó beneficiando a ciertos explotadores de minas en contra otros buscadores y de los propios Lakota Sioux- Un día a su regreso a Pine Camp, le preguntó a un comerciante, Challis Bill, el nombre de esa montaña. Bill respondió: "Nunca ha tenido un nombre, pero a partir de ahora, la llamaremos: Rushmore". Véase la página web del parque Mount Rushmore National Memorial: http://www.nps.gov/moru/index.htm. Consultada el 18 de abril de 2010.

${ }^{19}$ Ibid. 
(escogencia de lugares, materiales y modelación) a desdén de los efectos de la misma. Directriz que aquí se asimila al impulso desenfrenado de un Prometeo sin cadenas: una actitud pecaminosa o irrespetuosa del espacio natural en el que el monumento fue esculpido. Los residuos de los materiales restantes extraídos a la montaña de granito durante 14 años, aún permanecen sobre las copas de los árboles de pino, y las distintas especies (incontables plantas y animales) que en general fueron desplazadas, no han podido retomar el lugar o desaparecieron del entorno, señalando la completa indiferencia hacia las formas de vida, en un momento de absoluta confianza en la voluntad de dominarla.

\section{Declive del impulso prome- teico}

El caso montaña de los seis abuelos monte Rushmore hoy genera repudios por parte de activistas ecologistas, por ejemplo militantes de "Green Peace" quienes esgrimen argumentos en contra de la actitud agresiva del monumento hacia todo el entorno natural de las colinas de Negro (Black Hills), incluso se han llegado a realizar sabotajes mediáticos que ponen en entredicho la supuesta importancia del monumento y sobretodo, los valores americanos frente al abuso del medio natural. Como si se tratara del declive del impulso prometeico, no tanto por agotamiento de sus fuerzas como por el auto-reconocimiento de las consecuencias de sus actividades antrópicas, irreflexivas, la idea de Naturaleza resurge como la representación de algo sobre lo que se proyecta una responsabilidad humana, como aquí se ha querido entender: el resultado de un actuar errático y pecaminoso.

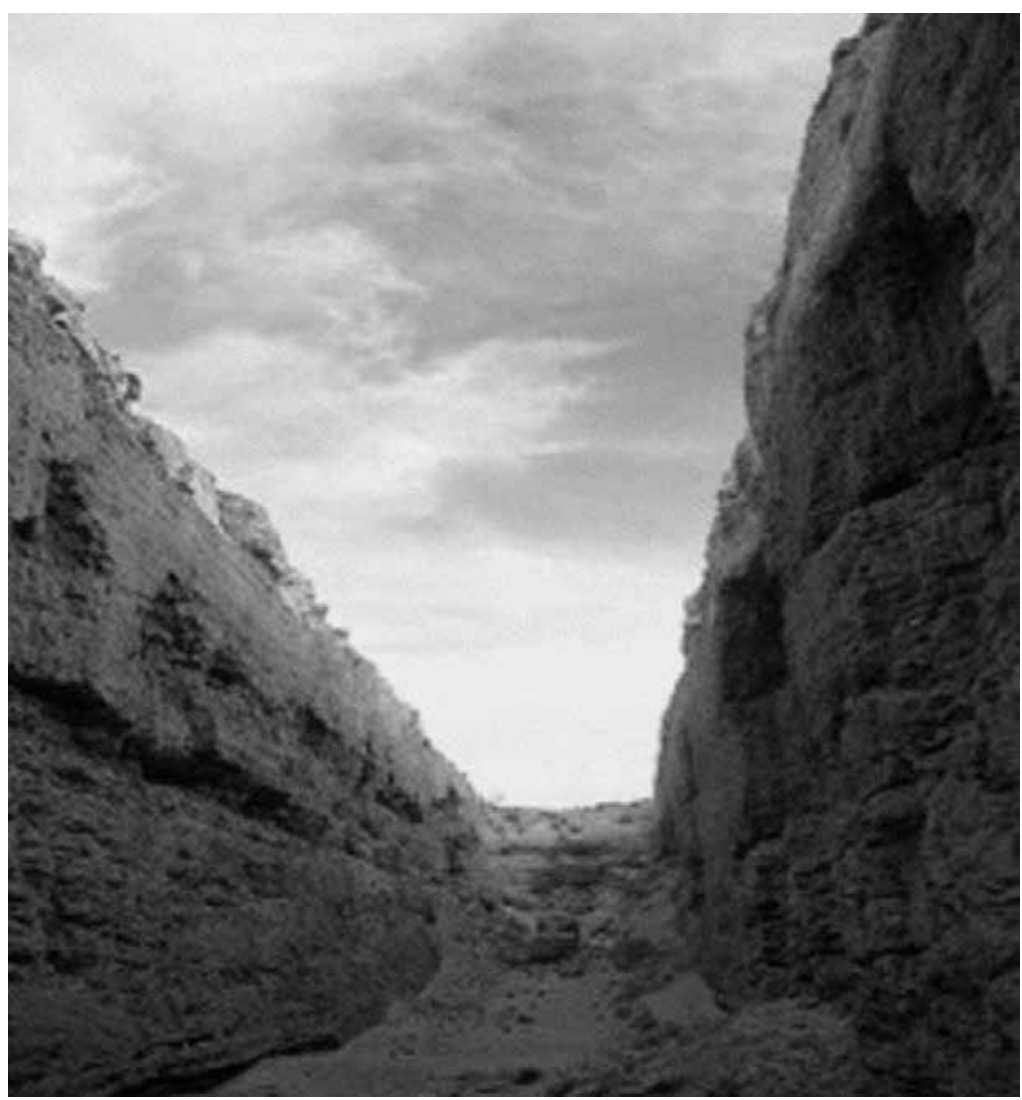

Figura 5. Michael Heizer, "Double Negative" Overton, Nevada, en 1969-70

Una acción prometeica como la de Borglum, de la cual se retomaría en su momento, el "esfuerzo", la tékhne ${ }^{20}$ o la destreza del saber hacer y los medios empleados para hacerlo, transforma el espacio natural en un perfecto artificio. Con respecto a dicha intervención, bien recibida por la sociedad del momento, puede señalarse como contrapunto, una acción similar pero no tan bien recibida como la vinculada a la creación de Double Negative de Michael Heizer (fig. 5 y 6). A la "reconquista del oeste" y alejado de estudios y centros urbanos, Heizer intervino un espacio natural pero fue fuertemente cuestionado ${ }^{21}$ por su grado de "irrespeto" hacia el entorno al remover casi 240.00 toneladas de tierra arenisca (Taylor, Mark C.1991, p. 45-51) para crear dos trincheras opuestas, excavadas en el borde de unas colinas del desierto de Nevada. El blanco de esa crítica señalaría cómo Double Negative asume el medio con indiferencia simplemente como un espacio abierto, un eterno vacío, que, según el autor, cuenta con una ausencia de Naturaleza, ella ni siquiera es un ornamento, sino algo asimilado a un gran lienzo o marco de presentación que se piensa negativamente. El mismo Heizer decía de su obra: "no hay nada ahí, pero sigue siendo una escultura" (p. 45-51), algo que sumado a la movilización de Bulldozers, el uso de escalas monumentales, helicópteros, etc. no podían esconder una actitud impía o babélica que evoca, a cuenta de la realización de un proyecto, la idea de que la técnica domina la Naturaleza muy a la manera de lo sugerido en la actitud indiferente de Borglum.

\footnotetext{
${ }^{20}$ Tékhne en la filosofía de Aristóteles era el saber hacer. Algo que permitía por medio del obrar, la transformación de lo natural gracias al uso de ciertas reglas o parámetros. Sin embargo, hoy, con la incorporación de la técnica moderna, esta conlleva a una sobre producción del artificio sobre la naturaleza sin reflexión alguna sobre los efectos de la misma. Véase: AA.VV. "Diccionario de Filosofía". (1997).

${ }^{21}$ Entre algunos de los críticos de esta actitud agresiva de Heizer se cuentan Dore Ashton, Michael Auping y Mirian Weisang.
} 


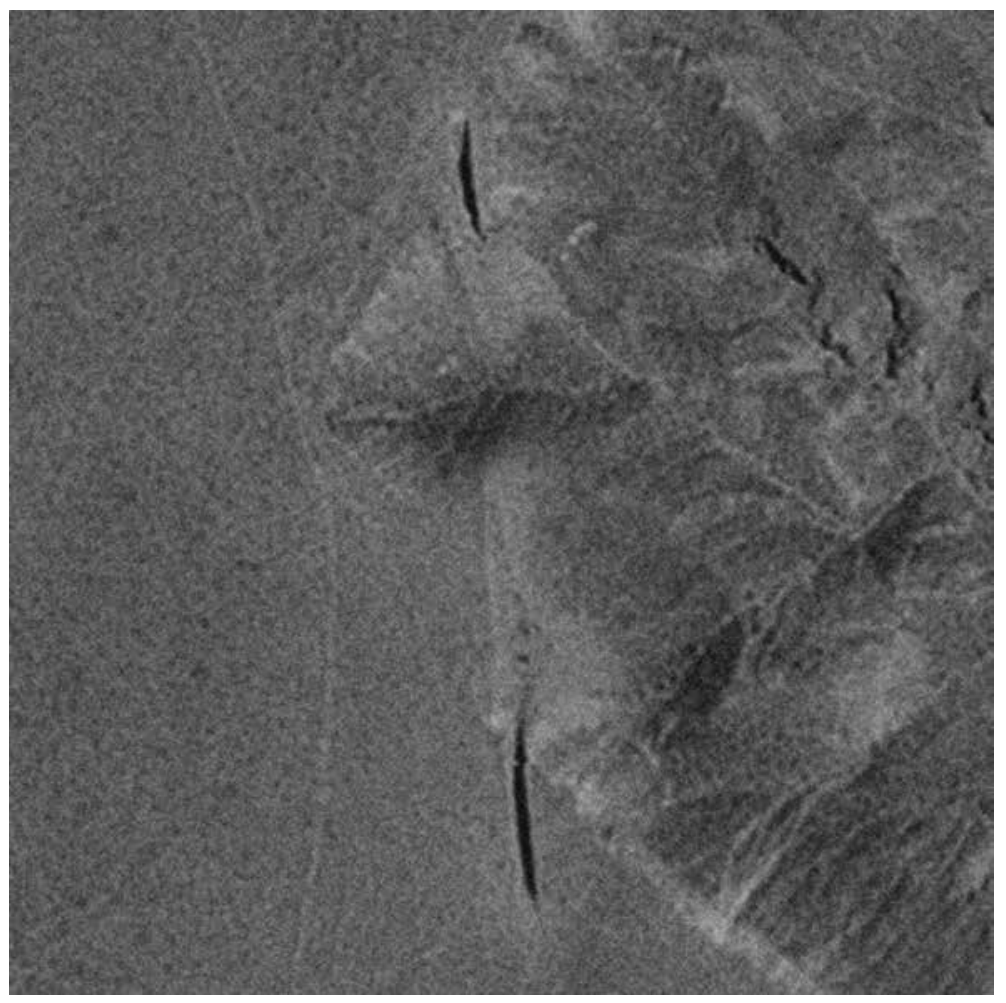

Figura 6. M. Heizer, "Double Negative" (Vista satelital)

La crítica a Heizer, que sugiere un acto prometeico de soberbia, está sustentada en una conciencia histórica que despierta ante la confrontación de la Naturaleza. No viene a ser sino hasta llegado el momento de conocimiento de la crisis ecológica de finales del siglo XX, que ella se considera en cuanto organismo vivo que la promesa prometeica de industrialización convirtió en valor de mercado. En esa medida, en la época de Heizer más que en la de Borglum, resulta consecuente el estado de conciencia social generalizada debido al desastre natural provocado de la escasa reflexión sobre el control y los efectos de la industrialización. Tanto Borglum como los mismos nativos originarios de Dakota carecían, en términos estrictos, de conciencia ambiental; el primero porque encuentra en la Naturaleza su valor de uso sin verla con cierta respetabilidad, los segundos porque sus formas de usarla, arraigada a concepciones cosmogónicas, no les permitirían vislumbrar, en ese momento, el estado ni las dimensiones reales del desastre ecológico alcanzado por las sociedades industrializadas.

En el panorama descrito, el carácter propio de la intervención de espacios naturales puede estar marcado por la imagen de una pecaminosa acción humana sobre el entorno que ha generado una crisis de la Naturaleza Pródiga, pero según lo dicho, esta es producto de la evidencia de los efectos de la inconsciente expansión del impulso prometeico. Esto hace que el cuestionamiento general por la manera de asumir y tratar la Naturaleza desde el pasado, viabilice un declive del impulso prometeico, algo que implica la emergencia de un nuevo marco de símbolos y neomitos que inciden en el arte, en la conciencia de una Naturaleza signada por la catástrofe. 


\section{Castigo: naturaleza en una instancia catastrófica}

Sabemos que el hombre blanco no comprende nuestro modo de vida. El no sabe distinguir entre un pedazo de tierra y otro, ya que es un extraño que llega de noche y toma de la tierra lo que necesita. La tierra no es su hermana, sino su enemiga y una vez conquistada sigue su camino, Trata a su madre, la Tierra, y a su hermano, el firmamento, como objetos que se compran, se explotan y se venden como ovejas o cuentas de colores. Su apetito devorará la tierra dejando atrás solo un desierto. No sé, pero nuestro modo de vida es diferente al de ustedes. La sola vista de sus ciudades apena la vista del Piel Roja. Pero quizás sea porque el Piel Roja es un salvaje y no comprende nada.

(...) esta tierra tiene un valor inestimable y si se daña se provocaria la ira del creador. También los blancos se extinguirán, quizás antes que las demás tribus. Contaminan sus lechos y una noche perecerán ahogados en sus propios residuos. Pero ustedes caminaran hacia su destrucción, rodeados de gloria, inspirados por la fuerza de Dios que los trajo a esta tierra y que por algún designio especial les dio dominio sobre ella y sobre el Piel Roja. Ese destino es un misterio para nosotros, pues no entendemos por qué se exterminan los búfalos, se doman los caballos salvajes, se saturan los rincones secretos de los bosques con el aliento de tantos hombres y se atiborra el paisaje de las exuberantes colinas con cables parlantes. ¿Dónde está el matorral? Destruido. ¿Dónde está el águila? Desapareció. Termina la vida y empieza la supervivencia". (Discurso del jefe Noah Sealth Seattle) $)^{22}$

\section{Retórica de la catástrofe}

A diferencia de la instancia pródiga de la construcción de la idea de Naturaleza en la que se infiere un ansia de proyección humana sobre el medio natural como dote, puede señalarse la instancia catastrófica de la Naturaleza asociada al castigo, no al fin o al ajusticiamiento final, sino a la puesta en riesgo del hombre y lo que lo lleva al arrepentimiento. La instancia catastrófica hace ver al hombre de las sociedades industrializadas como un intruso que se apropió y malogró lo puro existente y que sobrevive como ser castigado por una pecaminosa acción.

Con la industrialización de las sociedades sobrevino la denuncia por la explotación de las especies, la fauna, la flora, la mercantilización del agua, los minerales y "los recursos", por lo que distintas disciplinas (filosofía, vitalismo, bioética, ecología, historia ambiental, etc.) versan a menudo sobre una alteración de la relación tradicional entre hombre y la Naturaleza, dada por el ansia de dominio. Buck-Morss, S. (2004) llamó "el despertar de un sueño" a la reflexión sobre el dominio de la Naturaleza precursor de la Catástrofe ${ }^{23}$ ecológica; el sueño, ha puesto en riesgo al hombre gracias al desborde de la tecnificación y explotación de la cual la totalidad natural ha sido objeto. La Catástrofe es el resquebrajamiento del sueño o de la promesa de felicidad que se puso en marcha con la implementación del proyecto de dominio de la

\footnotetext{
${ }^{22}$ Tomado de: http://waste.ideal.es/sealth.htm. Consultada el 18 de abril de 2010.

${ }^{23}$ El concepto de "catástrofe", centrado en el texto de Susan Buck- Morss "Mundo soñado y catástrofe: la desaparición de la utopía de las masas de Este y el Oeste" (2004), hace referencia al resquebrajamiento de la confianza en el sueño de la fuerza de la industrialización en ambos mundos (URSS y USA) como opción utópica para el establecimiento de una calidad de vida óptima para las masas centrada en la explotación de la Naturaleza.
}

Naturaleza Pródiga, un despertar del sueño que traería consigo la concienciación que en efecto, la expansión de los saberes científicos y de la técnica en pro de la superproducción de objetos de consumo no traería un progreso para la humanidad sino un rompimiento con la Naturaleza y la indiferencia ante la pérdida de las condiciones generales de la vida en el planeta.

Cronológicamente, puede decirse que la reflexión de la idea de Naturaleza signada por el despertar del sueño de dominio ha generado desde la década de los setenta toda una retórica de la catástrofe natural. Si se entiende el término "retórica" como "el arte del bien decir" o como una manera de exponer y desarrollar argumentos convincentemente asociada al clamar y al persuadir, la evocación de ciertas imágenes referidas a la emergencia ecológica, medioambiental y ecosófica, serían muchas veces parte de una retórica de la catástrofe que conlleva más a la emotividad y al arrepentimiento, por una separación y afección humana de la Naturaleza, que a la evaluación de los contenidos desarrollados en la gran mayoría de discursos. Esta retórica, busca persuadir a un auditorio, al desplegar símbolos o realizar remisiones a concepciones asociadas a la desatenta actitud de las sociedades modernas hacia el medio Natural a diferencia de las sociedades primitivas.

Un ejemplo de dicha retórica de la catástrofe puede encontrarse en la famosísima carta o discurso del jefe Noah Sealth Seattle ${ }^{24}$ citada fragmentariamente en el exordio. Aunque en 1991 la periodista Paula Wissel ${ }^{25}$ demostró la vieja sospecha de que la carta era falsa, una patraña mediática reinventada en 1971 por un guionista de televisión llamado Ted Perry para un documental de la $\mathrm{ABC}^{26}$, la carta por lo demás, es una obra que sigue llevando a la conmoción, pues acude fiel y desesperadamente al desastre ambiental actual. La carta contiene elementos asociados a neo-mitos como el de la "madre naturaleza", el del "buen salvaje", el de la "naturaleza pura" y el de "la conquista de la naturaleza"; todo para señalar la perdida de la instancia pródiga, la pérdida de la pureza de la Naturaleza y el distanciamiento humano de la misma; para demandar la responsabilidad social e histórica por parte de las sociedades occidentales en el desastre. La carta es propia de nuestro tiempo, tal como esta retórica, remite a símbolos pertinentes al marco de la idea de Naturaleza catastrófica, no importa, si en el fondo incidía en los ratings, o resulta el falaz documento de base de muchos ecologistas, su función en el aparato mediático ha amplificado el sentimiento de arrepentimiento y la denuncia generalizada sobre la catástrofe ecológica que cala en el hombre de la sociedad actual, de allí su rotundo "éxito".

\footnotetext{
${ }^{24}$ El jefe "indio" Noah Sealth Seattle (1786-1866), es el supuesto representante de los Suquamish y Duwamish (nativos del actual estado de Washington) y negociador con los blancos sobre un injusto y forzoso tratado de ventas de sus tierras en el siglo XIX. Al parecer en 1854 pronunció un discurso a un gobernador llamado Isaac Stevens que fue reproducido por un periodista llamado Henry A. Smith. y que tradujo a lo que sería una supuesta alusión dirigida al entonces presidente de USA, Franklin Pierce. Véase: Murray Morgan, Skid Road, 1951, ISBN 0-295-95846-4 y también el artículo "Chief Seattle" en: www.wikipedia.com.

${ }^{25}$ Véase: http://www.snopes.com/quotes/seattle.asp

${ }^{26} \mathrm{El}$ documental, sin nombre, fue exhibido en un programa llamado

"Home" 1971 y en este se asumió que el discurso enunciado por Sealth ante una asamblea entre nativos y agentes del gobierno en 1854, antes escuchado supuestamente y reescrito en 1887 por un asistente llamado Henry Smith, era una carta del jefe mismo al entonces presidente de USA Franklin Pierce. Véase: http://www.atinachile.cl/node/2250 
La retórica de la catástrofe, que discurre sobre una pérdida de simbiosis armónica del hombre con la Naturaleza originaria con cierto aire de pecado teológico, es una evidencia del arrepentimiento de la confrontación humana de la totalidad natural propia de las sociedades industrializadas. Al evocar constantemente la ruptura de una concepción primitiva de la Naturaleza o del sentido de comunidad y de unidad que guardaban las sociedades ancestrales con el mundo natural, la retórica se hace síntoma de la Catástrofe. El discurso cuestiona la pecaminosa prometeización propia de las sociedades encantadas en el sueño de dominio, señala el paso de un uso convencional o respetuoso de la Naturaleza, tipificado en el imaginario social occidental sobre las culturas ancestrales, a un uso instrumental propio de la era industrial.

Es gracias al tono de la carta o a la retórica de la catástrofe que se sabe que ella no era propia del tiempo de Noah Sealth Seattle. En la carta, la industrialización, ya realizada, se asimila a un logro alcanzado gracias a una pérdida de cierto carácter pródigo que ancestralmente envestía a la Naturaleza y que la destrozó, pero Noah no vivió cerca de ciudad alguna, no hablaba inglés y en su tiempo el ferrocarril, los cables parlantes, la industria (incluso la aurífera y la agrícola) y la contaminación de ríos debieron serle ajenas, por lo mismo, no reconoció la extinción de ninguna especie cercana, menos del águila y el búfalo en Washington, además, puesto que perteneció a una nación que realizó un contacto tardío con los blancos, no fue testigo de una avanzada domesticación del caballo, tampoco era versado en la acepción del nativo como salvaje, ni podría servirse de tan empalagosa retahíla de frases cargadas de arrepentimientos catastróficos propias de imaginarios de hombres de otro tiempo.

Muy cerca de un "desencantamiento", esta retórica hace suponer que gracias a una creciente iluminación de la razón determinada por el grado de develamiento de la Naturaleza y el uso de la técnica, se desarrollaron las sociedades sin ninguna conciencia del usufructo del medio natural. La instancia catastrófica de la idea de Naturaleza surge en el imaginario de las sociedades industrializadas porque se funda en pruebas y explicaciones experimentales, determinaciones y utilidades sociales, pero sobretodo en la evidencia de su explotación. Las secuelas de la acción humana hacen pensar en un curso de la idea de Naturaleza desde lo idílico y pródigo, a un abuso técnico exagerado efecto del capitalismo (Geyer Carl,1985), a una instancia catastrófica, reconocida principalmente en la denuncia generalizada de dicha retórica que enfatiza en la perdida de una naturaleza pura u original y el distanciamiento humano de la "madre naturaleza".

\section{Test de pureza o conciencia artística de la catástrofe}

La retórica de la catástrofe acude reincidentemente a una pérdida de la pureza primigenia de la Naturaleza, un señalamiento con incidencias estéticas que se asocia a la sanción y la pérdida invaluable de la prodigalidad. Un ejemplo se tiene en la "Introducción a la arquitectura del paisaje" de Michael Laurie (1983), quien retomando un esquema propuesto antes por E. Gutkind ${ }^{27}$, señala cambios de actitud del hombre con respecto a su adaptación al entorno. Estos cambios, que podrían llamarse la fase del Temor, del mundo primitivo a la antigüedad; la fase del Respeto, hasta la revolución francesa; la fase catastrófica, en la modernidad hasta mediados del siglo XX y la fase de responsabilidad desde mediados del siglo pasado, se esgrimen como argumento para llamar la atención sobre la importancia de que el arte, en su caso, la disciplina de la arquitectura del paisaje asumiera una reflexión sobre el estado de destrucción natural.

El planteamiento de la pérdida de la pureza es un tópico que se funda en la evidencia de una actual destrucción de la Naturaleza:

La tercera fase -la catástrofe- ha desembocado en nuestra situación actual y en ella se encuentran las sociedades tecnológicamente avanzadas; se trata de una fase de agresión y conquista. (...) La relación yo-ello podría simbolizarse por la expansión urbana de nuestros dias, orientada por el automóvil, con un hinterland que ofrece bosques de árboles talados, explotaciones mineras agotadas y rios contaminados (...) tal es el resultado de una despersonalización de la naturaleza a través de la especialización científica que, desde el siglo diecinueve, hizo languidecer el conocimiento del vinculo entre el hombre y la naturaleza en toda su integridad. (Laurie, 1998, p.13).

${ }^{27}$ El texto citado por Laurie es: E. A Gutkind "Our World from the air: an international survey of man and his environment". New York. Garden City. 1952. 


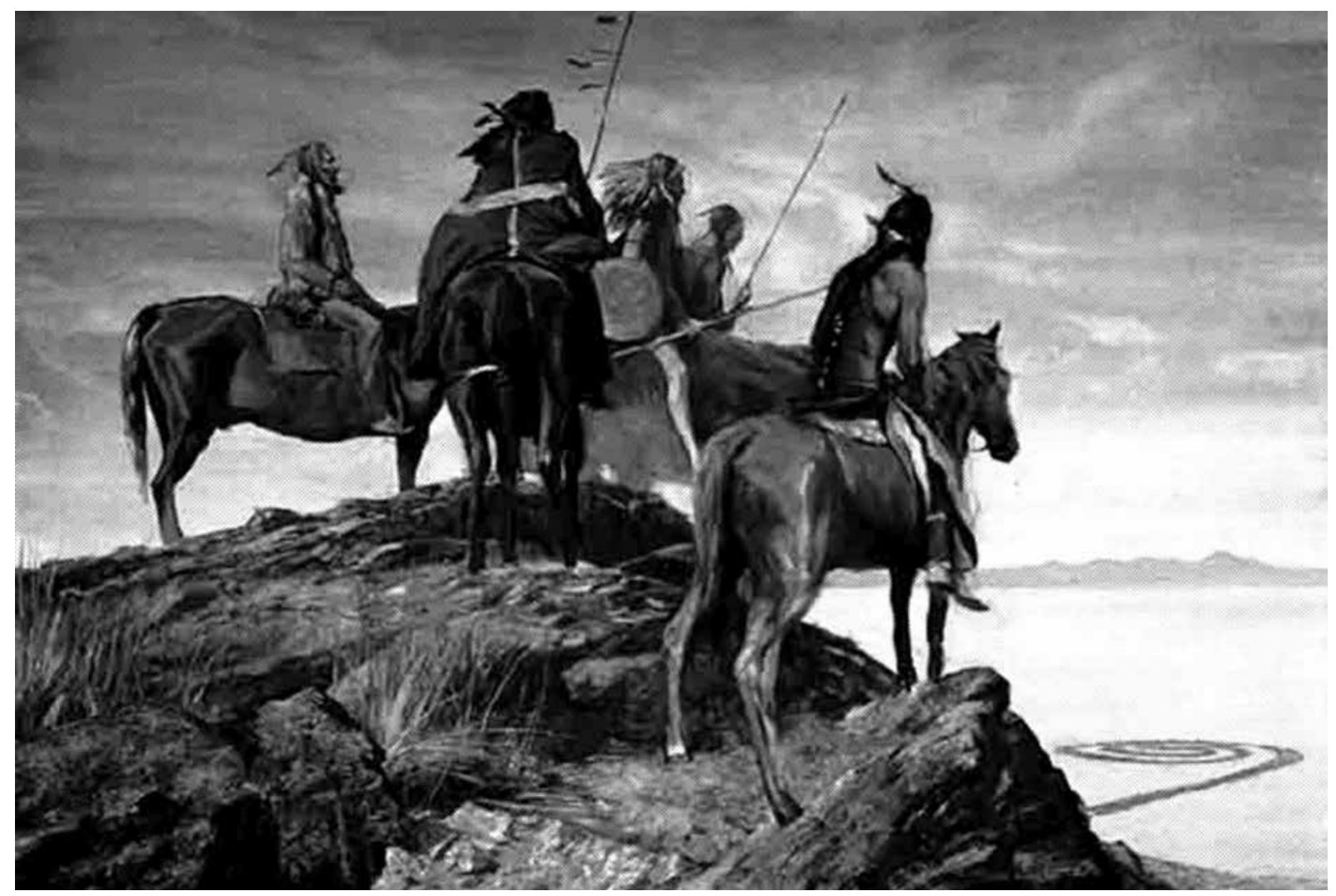

Figura 7. Mark Tansey. Purity Test [Test de pureza], 1982.

La pérdida de la pureza es un tópico neo-mítico para el señalamiento de la catástrofe actual. Algo que puede ampliarse relacionando algunos de los términos de la anterior cita de Laurie con el famosísimo óleo de Mark Tansey pertinentemente llamado "Test de pureza" (fig.7). ¿A qué pureza va el cuadro de Tansey? ¿Sugiere nuestra situación actual? ¿Habrían entendido los nativos originarios del lugar las formas emplazadas en el sitio y la contaminación del lago causada por explotaciones mineras ya agotadas cómo perdida de pureza? ¿Consideraría el aborigen la espiral emplazada por Robert Smithson en el Gran Lago Salado en Utah en 1970, una agresión al entorno? y de hacerlo ¿sería ello el resultado de una despersonalización? ¿Es una crítica del distanciamiento humano de la Naturaleza propio de las sociedades tecnológicamente avanzadas? ¿Acaso solo las sociedades posteriores al siglo XIX han hecho languidecer el conocimiento del vínculo entre hombre y la Naturaleza en toda su integridad?

La pureza de Tansey puede estar referida especialmente a la Naturaleza: a la pérdida de un supuesto estado original. En un artículo titulado "The American Sublime" Arthur Danto (2005), hablando de la pureza, señala que la espiral de Smithson re-presentada por Tansey se ha entendido bajo la metáfora de una imagen pura y que por tanto, en el cuadro, los indios, perplejos sobre la espiral, no saben que funciona como una obra de arte y hacen el intento de descifrarla como un símbolo. Danto señala también, que la pureza a la que se refiere Tansey radicaba en la respuesta de Smithson al reto greenbergiano, que en el contexto de la época exigía la búsqueda de lo específico a la pintura, la escultura etc. una búsqueda de la "pureza" del arte. Sin embargo Danto, arraigado en la tradición académica centrada en la obra de arte, no ve en el cuadro Naturaleza alguna, no tiene en cuenta ${ }^{28}$, ni a los nativos, ni su relación con el lugar del emplazamiento de la espiral, ni la crónica de Robert Smithson sobre el encuentro de un sitio que pareció evocarle las energías primordiales:"algo reverberó en el horizonte surgiendo un ciclón inmóvil, mientras la luz al entrar parecía iluminar un lugar azotado por un terremoto, un quieto terremoto expandiéndose en la luz centelleante con una sensación de girar, ipero careciendo de movimiento!" (Smithson, 1978, p.180).

\footnotetext{
${ }^{28}$ Esta pureza direccionada a lo artístico más que a la Naturaleza no es un caso aislado o es solo el caso de Danto, sino también el de Gary Shapiro (1995), quien en su prólogo, asevera que Tansey no se refiere a la búsqueda de un arte puro, sino que por el contrario evoca anacronismos propios del arte contemporáneo, los Nativos, la recreación de un heroico pasado americano, la espiral, el paisaje, etc. como recurso estético. En la misma línea está también Caroline A. Jones (1998).
} 
Es viable pensar que la pureza a la que Tansey se refiere está dada por el señalamiento de la pérdida de espacios naturales y de la naturaleza salvaje (wilderness). Purity Test parece una crítica de la vida moderna confrontada a la de los nativos en el oeste americano quienes se presentan como el símbolo de la vida primitiva. Si se asume no solo la existencia de dicha retórica, sino el esquema de unos estadios de develamiento de la idea de Naturaleza relacionados a la intervención de espacios naturales que proponía Laurie, Tansey sugiere una metáfora de la pérdida en tanto equipara en su pintura referencias asociables a perspectivas órfico-primitivas y prometeicomodernas. La espiral y los nativos son símbolos ${ }^{29}$ que en conjunto sugieren ideas ambiguas de pureza primordial, dada en un espacio natural convertido en un hinterland alterado y explotado por la acción del hombre y la técnica. Puntualmente la equiparación evoca el cuestionamiento por el entorno originario del Gran Lago Salado (Great Salt Lake) de Rozelle Point en el estado de Utah; pero por extensión, evoca un marco de símbolos en el que se observa una confrontación entre una visión primitiva, a la que se asocia el respeto al medio o al desarrollo de formas simbióticas para mantener un equilibrio vital capaz de mantener la pureza del entorno: y una visión utilitarista de la Naturaleza, propia de las sociedades industrializadas, que vino a fracturar dicho respeto/necesidad en la esperanza por cumplir sus promesas de felicidad.

El tema de Purity Test se relaciona con lo sugerido por Laurie, a una conciencia de la pérdida de la pureza y a un subsecuente arrepentimiento. El cuadro aquí se asimila a una ironía. El apelativo "pureza" sumado a la yuxtaposición de imágenes (espiral-nativos-), remarca la contradicción producida al juntar dos formas de pensar y usar el entorno incompatibles en un mismo marco. Ironía que se multiplica al pensar que la espiral de Smithson aparece como un símbolo referido al origen primordial en un lugar entrópico. Las interpretaciones de la espiral, en el arte rupestre americano, que para el caso serían las interpretaciones más cercanas de la espiral para los nativos, permiten suponer que en Purity Test, ella era un signo del origen primordial, una forma que recurre a un modo de asociación con algo que la hace significativa. La espiral que indistintamente se ha asociado al sol, al tiempo que se desenvuelve, al origen que tiene un punto del que se expande el todo, etc. sería sobretodo, signo del origen primordial, especialmente teniendo en cuenta que los mitos cosmológicos de los Shoshones sobre el gran lago utilizan la imagen de una espiral y remolinos subterráneos que lo generaron ${ }^{30}$.

En el cuadro de Tansey, la espiral es esencialmente, un símbolo anacrónico de la pureza asociado a las sociedades ancestrales, pero seguramente no sería una marca realizada, ni por los nativos americanos (Shoshones del norte de Utah o tal vez Navajos ${ }^{31}$ ), ni por la acción de la Naturaleza. Ella puede evocar un respeto religioso por los entornos, por ejemplo, en la alusión a los mitos cosmogónicos o del origen del gran lago salado de Utah, al relato de la gran corriente subterránea que lo unía al océano, lo que provocaba gigantescos remolinos en el embalse, torbellinos similares a espirales que seguramente invitaban a peregrinar a un lugar sagrado; por eso, la espiral evoca la pureza en la impureza, emplazada en un lago mancillado, ornamentada con pozos de extracción petrolera agotados o canteras de sulfato de magnesio, como signo marcado en el territorio a partir del uso de maquinaria, corresponde al ansia smithsoniana por territorializar ${ }^{32}$ un mito y por realizar una acción artística sobre un sitio impuro.

\section{Rompimiento con la Chöra como desavenencia}

La retórica de la catástrofe, vista como relato que versa sobre un periodo de rompimiento en que se fractura la concepción órfico-primitiva, y las explicaciones mágicas de la Naturaleza propias de la antigüedad, discurren sobre la pérdida de un antiguo status de la Naturaleza, una desmitificación que la alejó del estado unitario o fraternal que mantenía con el hombre. Tansey, con las incompatibilidades evocadas en Purity Test, remite a una conciencia actual de la pérdida de un estado original de la Naturaleza y los espacios naturales luego

\footnotetext{
${ }^{29}$ El símbolo representa en tanto permite comparaciones alegóricas a una situación como por ejemplo las dadas en el mito. Véase: "símbolo", "signo" en AA.VV; "Diccionario de Filosofía" (1997)

${ }^{30}$ Sobre esta versión del mito del origen del Gran Lago Salado que versa sobre una unión del lago y el mar gracias a corrientes subterráneas que producían siempre inmensos remolinos en el centro del embalse puede verse en Galofaro (2003, p.74) y en la interpretación de la espiral que hacen Shapiro (1995) y Hobbs (1981).

${ }^{31}$ No se sabe a ciencia cierta de qué nación son los nativos que representó Tansey, si son originarios de Utah o no, pues solo se asimilan a cazadores del oeste. Danto (2005) asevera grosso modo que son "Indios" como los que pintara Remington. Caroline A. Jones, en su texto "Machine in the Studio: Constructingthe Post War American Artist" (1998, p. 334 -336) menciona que debido a su uso de mantas y caballos, los aborígenes son Navajos y que se encuentran de paso por el entorno del gran lago salado en Utah, sin embargo, los Shoshones del Norte de Utah domesticaban caballos y comerciaban con los españoles, antes de la llegada de blancos a Nevada y Dakota, conocían el sitio, el cual tenía para ellos especial connotación puesto que conservaban la leyenda del origen del gran lago, y sus atuendos no son especialmente de alguna tribu o nación. A este respecto este trabajo se remitió especialmente a: Albers, Patricia C. (2001, p.761-776).

32 Por territorialización, término entendido dentro de la arquitectura de los artscapes o del paisaje, se entiende la intención de resignificar un espacio por medio de la materialización de un lenguaje. En la medida en que la espiral se crea como un emplazamiento que establece un dialogo con el entorno, permite superar la noción clásica del espacio mismo. La espiral que es un signo que remite o señala el mito cosmogónico del Gran Lago Salado, por lo menos en el caso de la pintura de Tansey, sería pues una territorialización de dicho símbolo. Entre los que ya han entendido la espiral como territorialización del mito, véase: Galofaro (2003, p. 74).
} 
de la industrialización transformadora de los entornos y el desarrollo del modelo de vida que conllevó a la catástrofe. Pero esto sería el producto de un distanciamiento de la Naturaleza dado por la consecución de un estado de confianza general en las fuerzas humanas apoyadas del uso de la técnica, algo que redujo ese respeto que "las sociedades no avanzadas tecnológicamente" tenían por el medio natural. Estas fuerzas humanas, derivadas de la acción expansiva de la racionalidad, trajeron consigo la posibilidad de conocer y fragmentar la Naturaleza para transformarla agresivamente en términos de los intereses mundanos, algo que requería de un desconocimiento de la unidad originaria del hombre con el medio natural ${ }^{33}$.

En Purity Test, el señalamiento sobre un rompimiento del statu mítico de la Naturaleza se presenta en la referencia a un distanciamiento de las sociedades industrializadas de la "madre originaria", esta última, propia de las sociedades que aún no han hecho "languidecer el conocimiento del vínculo entre hombre y la Naturaleza en toda su integridad" como sería el caso de los Shoshones. Para el imaginario occidental, la Naturaleza en la cosmovisión nativo-americana, equivaldría a la "madre originaria", pero ese reconocimiento es típico, tanto de las sociedades nativo-americanas, como de las sociedades occidentales, pues el término "naturaleza" -un nombre femenino-tiene el carácter de lugar originario y de vínculo fraternal, por lo que no es extraño asociarlo a una madre ${ }^{34}$.

En los orígenes de la tradición occidental, se feminizaba o equiparaba a la naturaleza misma con la mujer como factor esencial del origen y la labor reproductiva, matriz-receptáculo ${ }^{35}$ para el hombre-hijo desprovisto de autosuficiencia. Pere Salabert en "El mundo en un cuadro de familia" (2006), señala que desde la antigüedad la filosofía ha realizado una entronización y feminización de la Naturaleza, cuestión que se refleja en la construcción mítica de la misma en el Tímeo de Platón, en donde, sexualizada como la "Chöra" ${ }^{36}$, ella se convierte en un lugar originario sin ser un lugar en sí misma, "una matriz de todas las cosas" (Platón; Tímeo: 50c-51c). Para Platón es necesario recurrir a una explicación sobre la naturaleza como physis porque a pesar de centrar el fundamento de la realidad en lo inteligible debe sustentar la existencia del mundo terrenal. El mundo sensible no ha sido creado de la nada, es materia preexistente, por ello, debe hablar de un principio o substrato material eterno primigenio y caótico, aunque no radicalmente en contra de Demócrito. Platón sugiere un substrato que debe ser fecundado por el demiurgo creador (fundamento inteligible: orden) para dar lugar al mundo sensible como una copia. De esta forma la Naturaleza se presenta sexualizada por su contraposición propia al demiurgo, su principio es el de matriz de todas las cosas, pues provee posición o lugar a todo lo que existe, su caos se refiere al mundo de los fenómenos, al devenir inaprensible.

La Naturaleza se ha sexualizado, pero también se ha personalizado y despersonalizado. En los planteamientos de Laurie, las relaciones hombre- Naturaleza se explican en el marco de las relaciones psicosociales yo-ello. En otras palabras, para describir la historia de esas relaciones, Laurie, propone un esquema psicosocial (yo-tú/ yo- ello), estableciendo el paso de la relación de parentesco yo-tú (temor- respeto, de la antigüedad al renacimiento), que representa la mutua adaptación entre hombre y naturaleza, a la relación de propiedad yo-ello (modernidad- contemporaneidad) que representa la desavenencia. El Rompimiento y la agresión a la Naturaleza vienen a señalar su "despersonalización" ${ }^{37}$. Algo que acerca a Laurie y a Salabert pues la pérdida de familiaridad (yo-tú) o el desconocimiento del hombre que rompía el vínculo con la Naturaleza tiene que ver con la perdida de personificación de la misma.

Conocer la Naturaleza bajo la perspectiva prometeica sumado a la utilidad instrumental de su develamiento, a fuerza, le quitaron al término cualquier viso de materna-feminidad y produjeron un extrañamiento de las sociedades industriales de su propia "Chöra", algo que permitió al hombre un reconocimiento de sí, sin

\footnotetext{
${ }^{33}$ Muy cerca de esto, en "Dialéctica de la ilustración" (1994) Horkheimer y Adorno sugieren una escisión del hombre de la Naturaleza; primero refiriéndose a una etapa del encantamiento, en la que el pensamiento del hombre se adapta miméticamente a la naturaleza por el desconocimiento científico de sus leyes, y luego distinguiendo una etapa de tránsito en las que las formas de razonar pasaron del uso especulativo del pensamiento mítico al uso experimental del pensamiento racional. La racionalidad moderna crea leyes formales, principios y axiomas que exponen a la naturaleza sin dejar fisuras. Sin embargo, su rebasar del mito no es más que la adopción humana de un haz de leyes que limitan la acción de la razón y de la naturaleza en sí. Precisamente en la "Dialéctica de la ilustración" se plantea que aquello que los hombres quieren aprender de la naturaleza es a tomar distancia (desmitificarla) para utilizarla según fines de dominio. Véase también Geyer Carl (1985).

${ }^{34}$ El término "naturaleza" viene del latín natura asociada al verbo nascere: nacer, tal vez a la designación de los procesos naturales y no a los objetos naturales.

${ }^{35} \mathrm{La}$ idea que maneja Pere Salabert es que la mujer es madre (lo producido y a la vez el productor) y se asimila a la naturaleza pues ella es materia inerte y a su vez, forma recreadora del todo. Salabert (2006, p. 21).

${ }^{36}$ La Chöra es la "madre naturaleza" platónica en el sentido de matriz física originaria. Se conserva el término y la forma de escribirlo con el fin de diferenciarlo de una acepción de "madre naturaleza" popular o cercana al folklore que aquí no es objeto de análisis.

${ }^{37}$ Esta idea de personalización/despersonalización se encuentra en Laurie, pero a ella también recurre Hadot (2005, p. 44) en términos de personificación / despersonificación.
} 
concebirse en la Naturaleza, en familia o uno mismo con ella. Este reconocimiento de- sí sería precisamente basado en el desconocimiento de su vínculo con la Naturaleza. En la explicación de Laurie (1983) sería el paso de la relación fraternal yo-tu, al paso de las relaciones entre extraños, yo-ello, lo que llama la despersonalización; en la explicación de Hadot (2004), sería el paso de una Idea de Naturaleza marcada por las divinidades (personificación) como Zeus, Poseidón o Artemisa y su poder sobre los fenómenos naturales a la explicación de esos fenómenos en términos de develamiento humano (despersonificación).

En los términos evocados de la relación entre Purity Test y los planteamientos de Laurie, el distanciamiento no es provocado por una concepción órfico-primitiva de la Naturaleza-por ejemplo, la asociada a los Shoshones del Norte- sino porque el hombre moderno con su actitud prometeica siente mucha confianza en sus propias posibilidades de conocer por medio de la ciencia y de manipular por medio la técnica, desconociendo el vínculo con la "Chöra". El distanciamiento o la emergencia del hombre frente a la Naturaleza, ahora catastrófica, el paso a un exacerbado trato irrespetuoso o simplemente técnico de la misma, deben darse como rompimiento del sometimiento fraternal a la ley divina y a un antiguo mundo simbólico, dado gracias al acogimiento a los preceptos de la racionalidad propios de una sociedad industrial.

La instancia catastrófica de la Naturaleza es en sí un castigo al hombre. Es una muestra de poder de la divinidad resultado de la prolongación de la desavenencia. El castigo es una acción preventiva, no un ajusticiamiento final o apocalíptico, sino una acción que conlleva al arrepentimiento. Ante la concienciación de los nocivos efectos de la acción humana sobre la Naturaleza sugerida en la retórica de la catástrofe y sus referencias a la perdida de la pureza y al distanciamiento humano del medio natural, el castigo, se presentan posibilidades o planos de inmanencia para el desarrollo de propuestas de solución ante un apocalíptico futuro que parece devenir.

\section{4. Ética de la salvación: naturaleza en una instancia apocalíptica}

"Destruiré por completo todas las cosas de sobre la faz de la tierra, dice Jehová. Destruiré los hombres y las bestias; destruiré las aves del cielo y los peces del mar, y cortaré a los impios; y raeré a los hombres de sobre la faz de la tierra..." (Sofonías 1:2)

\section{Revelación apocalíptica}

Los mitos escatológicos ${ }^{38}$ tienen un tono profético, sugieren una etapa de ajusticiamiento a los hombres por medio de fenómenos como cataclismos, diluvios, sequías, huracanes y terremotos. El fundamento de estos mitos está en el miedo y el respeto a la deidad quien posee el control de elementos primordiales como agua- fuego-aire y tierra. De la misma manera, ciertos relatos propios de una mitología medioambiental de las

\footnotetext{
${ }^{38}$ La escatología versaba originalmente sobre relatos del final de los tiempos y la muerte de la humanidad, premios y castigos de ultratumba etc. véase el artículo "Escatología". En: A.A.VV; "Diccionario de filosofía”. Ed. Panamericana. Bogotá. 1997

sociedades industrializadas, participan de un tipo de pensamiento- tratamiento sacralizado de la Naturaleza que la asume con una conducta pseudo religiosa. Simbologías de lo dantesco, voces acerca de profecías milenarias que vaticinan un cercano juicio final, un ajusticiamiento armagedónico, pronósticos cataclísmicos y demás, son algunos de los tópicos neo-míticos que revelan un futuro final acompasado de incontrolables fenómenos naturales como retribución a la reincidente impiedad humana; sin hacer parte de una religión positiva, sino de un canon de imperativos biocéntricos, estos tópicos propician el culto a la Naturaleza al reconocerla como originaria, poderosa y en afrenta.

Más que anunciar el fin del mundo, los mitos escatológicos narran las consecuencias de la impía actitud humana del pasado proyectadas causalmente a un futuro hipotético. El mismo término "apocalipsis" significa "revelación", remite a la manifestación de un secreto que predestina el final de la degradación humana resultado de desafiar a la deidad. La revelación apocalíptica es ante todo, una advertencia dictada frente a la ira de la deidad, anuncia el final de los tiempos como verdad conveniente para propiciar la salvación humana, de esa forma resulta ser más que la destinación a un ajusticiamiento sin salida, se convierte en una instancia que forja el miedo y el respeto a la deidad: en lo apocalíptico se anuncia el fin y especialmente, la salvación.

Ya que en las sociedades industrializadas la idea de Naturaleza deviene de un proceso de construcción que implica un arraigo histórico desde lo pródigo a lo catastrófico, pareciera que el pensamiento e intervención de la Naturaleza insta a perseguir una conclusión futura o un fin en el que se produce el cierre de un ciclo en desarrollo a la manera de los mitos escatológicos. Esta imaginería de un fin histórico puede sustentarse como un profético anuncio de salvación propio de una instancia apocalíptica de la construcción de la idea de Naturaleza. Es la salvación y no el exterminio la esencia de lo revelado, de allí que en la instancia apocalíptica se promueva la búsqueda de la gracia, del favor divino.

La instancia apocalíptica en la construcción de la idea de Naturaleza se sustenta en la evidencia de que los actos humanos resultan afecciones del medio natural que pueden desencadenar un ajusticiamiento definitivo. Es una instancia en la que se anuncia la necesidad de regular estos actos para alcanzar la salvación desde imperativos morales no instrumentales hacia medio natural. La revelación está dada para promover actos que validan una doctrina, la legitiman y perpetúan. En el campo de producción simbólica de las sociedades industrializadas estos actos abogarían por mejorar el presente señalando una esperanza de redención de la Naturaleza, algo que se sugiere en adelante, a partir de la trasposición de los mitemas de la mitología de la redención (pecado, castigo, salvación) a la relación hombre-naturaleza actual y el abordaje de la intervención artística de espacios naturales como acto ritual. 


\section{Pecado, castigo y salvación}

Y dijo Jehová Dios: He aqui el hombre es como uno de nosotros, sabiendo el bien y el mal; ahora, pues, que no alargue su mano, y tome también del árbol de la vida, y coma, y viva para siempre. Y lo sacó Jehová del huerto del Edén, para que labrase la tierra de que fue tomado. (Génesis 3:22-23).

Los mitos de la redención ${ }^{39}$ son mitos escatológicos, pretenden vislumbrar el futuro, permiten acudir a una condición inicial de confrontación hombre-deidad; simbolizan la condición humana, la culpa hereditaria, la ofensa a la deidad y el riesgo futuro de muerte, permiten inferir que existe la posibilidad de arrepentimiento, la esperanza de reencontrarse purificado del pasado en la búsqueda de abolición de la pena. Además cuentan con mitemas como pecado, castigo, salvación y héroes mitológicos que realizan una misión ante la adversidad. La Redención surge en una instancia apocalíptica porque busca la liberación del pasado para la salvación del exterminio, implica una remisión al origen del pecado.

En una instancia apocalíptica de la construcción de la idea de Naturaleza propia de la mitología escatológica actual, los mitemas de los mitos de la redención "pecado-castigo-salvación" se equiparan a los términos de un ansia humana redentora de la Naturaleza: la desenfrenada soberbia humana se asimila al pecado, la catástrofe natural al castigo, y la salvación humana, a la esperanza de la redención de la Naturaleza.

El pecado es el primer mitema en el ciclo de redención humana, es la autodeterminación frente a la deidad, algo que lo hace asociable sobre todo, a un acto soberbio como la búsqueda emancipada por develar y usar a la Naturaleza. Es gracias al pecado que la Naturaleza pródiga se asimila al lugar al "este del Edén" ${ }^{0}$. El hombre se encuentra en perfecta armonía con el entorno ${ }^{41}$, goza de los beneficios de estar en naturaleza pero siente la tentación de que sus propias fuerzas lo pueden llevar a superar las fuerzas de la misma. La perfecta armonía se quiebra.

Como si la Naturaleza se ofuscase ante el pecado, la sagacidad, el ansia de develamiento y la confianza en su dominio por medio de las fuerzas humanas, lanza sobre el hombre el castigo que lo confronta a fuerzas superiores indomables. La posesión soberbia de conocimientos y prácticas de explotación de la Naturaleza, a desdén del fundamento originario de la vida y sus leyes, resultan pecados castigados, falaces promesas de felicidad como las que configuraron a las sociedades en camino a la industrialización fielmente adscritas

\footnotetext{
${ }^{39}$ Por ejemplo el relato de Redención humana dado luego del concilio de Trento, que interpreta de varios de los hechos narrados en el tercer y cuarto libro del Génesis que hacen referencia a la vida del hombre en el jardín del Edén y a su desobediencia a Dios como el inicio de un ciclo de caída y salvación con un límite o cierre en el apocalipsis. Véase: Rodriguez, Lanzetti (1982).

${ }^{40}$ En el Génesis este lugar al oriente del Edén, era un huerto al parecer bien irrigado ya que estaría localizado cerca del Éufrates, un lugar tan especial que en él se paseaba el mismo Dios: "oyeron la voz de Jehová Dios que se paseaba en el huerto, al aire del día; y el hombre y su mujer se escondieron de la presencia de Jehová Dios entre los árboles del huerto. Mas Jehová Dios llamó al hombre, y le dijo: ¿Dónde estás tú? Y él respondió: Oí tu voz en el huerto, y tuve miedo."(Génesis 3:8-10)

${ }^{41}$ Los hombres vivian armónicamente con la Naturaleza teniendo en cuenta lo dicho en Génesis 2:15: "Tomó, pues, Jehová Dios al hombre, y lo puso en el huerto de Edén, para que lo labrara y lo guardase” a lo que se contrapone lo dicho por Dios a Adán al castigarlo: "maldita será la tierra por tu causa; con dolor comerás de ella todos los días de tu vida”.
}

al impulso prometeico. El castigo no es definitivo, es un estado peregrinante, pone en evidencia el riesgo que corre el hombre de continuar con su actitud instrumental, lo hace asumir su propia condición escindida de la Naturaleza y lo lleva a sentir vergüenza de su propia soberbia, a un constante arrepentimiento.

Los mitos de la redención proyectan la imagen del hombre como la de un ser signado por la búsqueda salvación y la superación del arrepentimiento al corregir un mal accionar. Pero el perdón positivo no existe, solo puede ser alcanzado en el futuro, llegaría a ser esperanza eterna, búsqueda utópica y constante. La totalidad que sostiene la vida humana ya no puede dar todo por sí sola, los propios hombres arrepentidos deben asumir acciones "solidarias" y corregir el pasado o resignarse a perecer, por eso, puede decirse que en las sociedades tecnológicamente avanzadas, el castigo actual como advertencia futura pretendería ser mitigado con acciones que se asimilan a la búsqueda de salvación humana.

Habría que agregar que en esta equiparación de mitemas de la redención, los héroes serían los hombres que dominan los impulsos órfico-prometeicos. Generalmente la redención se ha referido a la situación humana frente a la deidad, pero por extensión, puede referirse a la Naturaleza, no por trasposición de personajes, sino porque actualmente para conseguir la salvación humana, se debe contar con una redención de la Naturaleza ${ }^{42}$. La Naturaleza debe ser redimida a menos que el hombre se resigne al final de los tiempos. Para el hombre la Naturaleza pródiga ha sido afectada, se ha perdido la armonía y debido a la catástrofe se encuentra en una mala situación, el mismo hombre se encuentra en riesgo y debe restituirla. El hombre como redentor y personaje signado por la necesidad de salvación debe liberarla de su propio interés instrumental y restituirla del yugo para no perecer. Ante el riesgo de un ajusticiamiento definitivo, por ejemplo en la destrucción ambiental, surge la necesidad de Redención de la Naturaleza. Una necesidad utópica pues no se cuenta con la certeza de conseguirla, sino con la posibilidad y los medios humanos para alcanzarla como fin concreto en el porvenir, por ello no puede más que asimilarse con la esperanza en el devenir histórico.

\section{Esperanza de redención o equilibrio Órfico-Prometeico}

"Si la técnica no se reconcilia con la naturaleza, esta se rebelará" (Juan Pablo II, 2000 discurso Homilía en el Jubileo de los agricultores 12 nov. 2000)

El margen establecido entre una instancia de pecado originario y el exterminio final o la correspondencia entre los mitemas de las instancias pródiga, catastrófica y apocalíptica, con la dinámica reciente de las relaciones hombre-totalidad natural quiere señalar que la idea de $\mathrm{Na}$ turaleza, es en buen grado orientada por preceptos éticos homologables a cánones de la $\mathrm{fe}^{43}$. Lo apocalíptico nunca

\footnotetext{
${ }^{42}$ Sobre la interpretación del mito del pecado original referida a la establecida en el concilio de Trento que versa sobre la redención humana y a su extensión a una redención de la Naturaleza vale la pena acercarse a Romanos, capítulo 8.

${ }^{43}$ La fe está arraigada en la creencia y la esperanza, es ante todo un compromiso para con el futuro con repercusiones en las acciones desde la moral. La fe de salvar la Naturaleza y por tanto, al hombre, de la catástrofe ecológica, es la posibilidad futura mediada por acciones comprometidas.
} 
supone un exterminio inmediato, sino un límite final de un extenso recorrido. Si en las instancias pródiga y catastrófica la descontrolada búsqueda de felicidad de las sociedades industriales desató unas fuerzas naturales de exterminio desconocidas o antes encadenadas, lo apocalíptico aboga por la rectificación moral de dichas sociedades sugiriendo la esperanza o la fe en una oportunidad de liberación de una culpa que desde el pasado marca el presente. Los hombres deben disponerse a rectificarse, no solo asumir el castigo y seguir conformes hacia el fin, sino pensar e intervenir para restituir a la Naturaleza y a pesar de que eso no se pueda lograr al punto de retornar a la instancia pródiga, la esperanza marcaría la continuidad del nexo con la Naturaleza potenciando la prolongación de formas de subsistencia para el hombre.

La salida al castigo actual parece inferirse, no de la corrección total del impulso prometeico y el retorno al estado de encantamiento, sino de la esperanza en un futuro que salda cuentas con el pasado. Determinar en qué medida la perspectiva prometeica debe seguir siendo la motivación dominante del develamiento de la idea de Naturaleza y de la relación del hombre con ella, como forma de esperanza y rectificación, no implica, una emergencia totalitaria de la perspectiva órfica; no se puede arrinconar a Prometeo; sin él, las opciones de subsistencia frente a la catástrofe ecológica no son sensatas, pero tampoco puede desestimarse la guía de Orfeo, puesto que las opciones para con la Naturaleza serían labores mecánicas que no redundarían en la prolongación la vida sino en los intereses humanos.

Figura 8. Buckingham. (2002)."The Six Grandfathers,PahaSapa, in the Year 502,002 C.E.

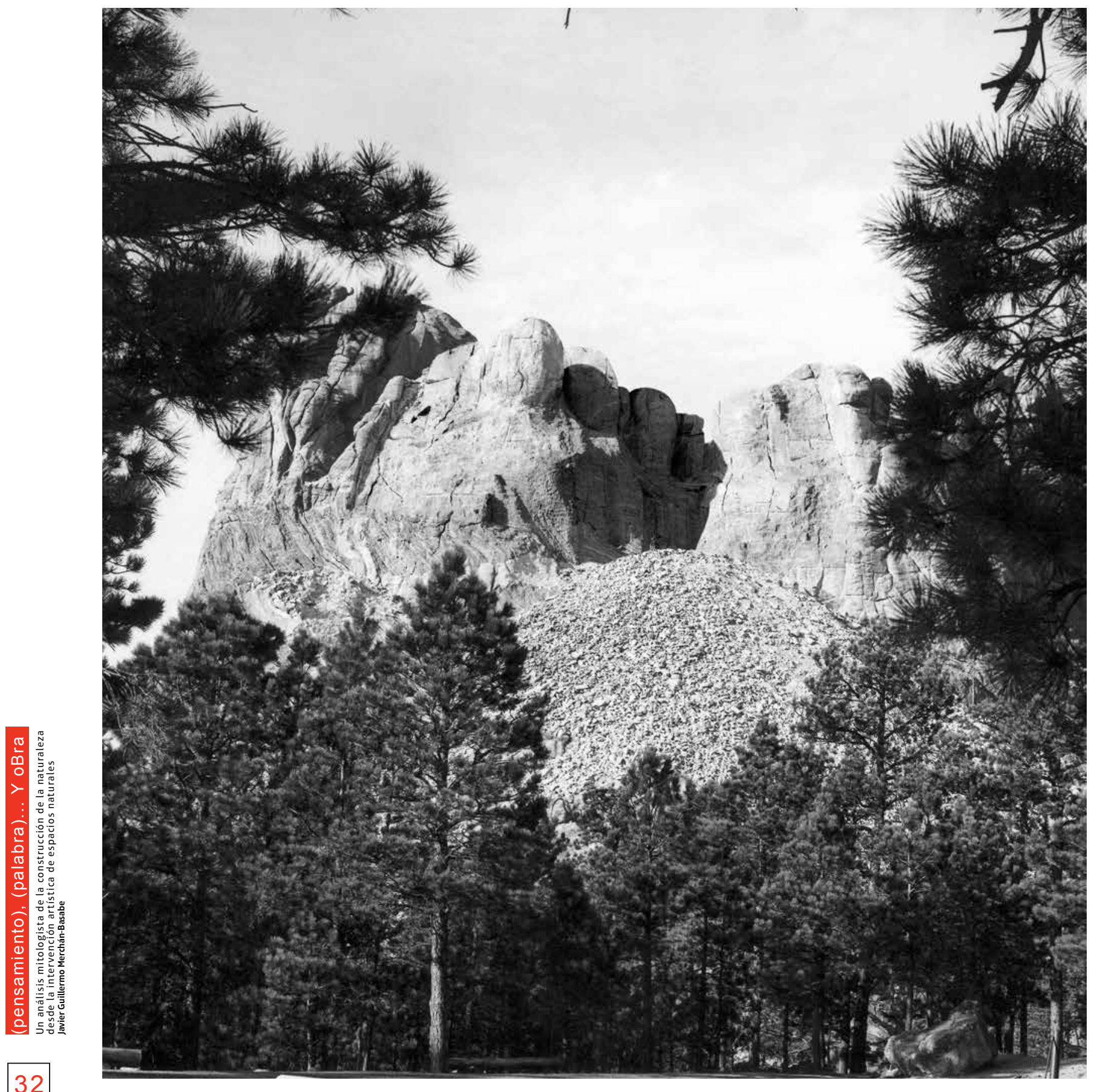


La búsqueda de equilibrio órfico-prometeico cala en el pensamiento de la intervención de sobre Naturaleza haciéndose imperativa (véanse fig. 2,3 y 4). Así lo sugiere el retoque digital de una fotografía de la montaña de los seis abuelos/monte Rushmore (fig.8) con las cuatro efigies talladas allí, realizado por el artista gráfico Matthew Buckingham. "Los seis abuelos, Paha Sapa, en el año quinientos dos mil $(502,002)$ de nuestra era" ${ }^{44}$, invita a pensar la acción realizada en la construcción de las cuatro efigies o el monte Rushmore, la talla y todos los símbolos asociables a ella, en un lento retorno a la naturaleza original, por tanto, aquí el retoque invita también a una crítica de la construcción histórica de la idea de Naturaleza y del usufructo de la sociedad industrializada; primero porque muestra cómo se vería la montaña erosionada 500.000 años $^{45}$ más tarde, lo que sugiere que el triunfo humano o la conquista de la Naturaleza propia de la actitud prometeico-moderna no ha sido más que un gesto efímero; segundo, porque la acumulación de material desprendido ha crecido bastante y no parece notarse una antropización significativa del entorno, lo que señala que la Naturaleza ha retomado la montaña a pesar de la influencia de la humanidad, lo que se esperaría para su pervivencia a futuro. Aunque es difícil saber que en 500.000 años la montaña sea así, Buckingham hace al pensamiento reconocer la idea de Naturaleza usurpada por el hombre con la esperanza de restitución futura.

\section{Estética de la redención}

"Es tan rabiosamente actual el modelo de una naturaleza debilitada a expensas de nuestra capacidad técnica, que no resulta demasiado arriesgado afirmar que la linea de intervenciones minimas, donde ante todo se resalta el deseo de integración en el medio, y la ética del respeto por los ecosistemas en los que se interviene, acaba siendo moralmente más celebrada; mientras que, por el contrario, ya resulta dificil recabar un apoyo unánime ante proyectos grandilocuentes, como se ha podido comprobar con la polémica suscitada por algunas propuestas de Christo o la marcada oposición del ecologismo pero también de algunos sectores de la cultura, ante el proyecto de Chillida para la montaña de Tindaya. La naturaleza en sí misma va adquiriendo condición de respetabilidad, siempre y cuando se muestre arropada por sus arquetipos más sólidos" Albelda $(2004 \text {, p. } 7)^{46}$.

\section{Ideal estético y ritual de la redención}

El exordio señala una manera de asumir la crítica de la intervención artística sobre la Naturaleza, desde nociones como naturaleza debilitada y respetabilidad, evocando una histórica

\footnotetext{
44 “The Six Grand fathers, Paha Sapa in the year 502,002”. Paha Sapa era el nombre con el que los Sioux reconocían el valle y la cadena de picos y montañas en el que se encuentra la "montaña de los seis abuelos"

${ }^{45}$ En los textos adjuntos a esta fotografía dispuestos como apoyo para la exposición se señala que los geólogos creen que tomará aproximadamente 500.000 años para que los retratos de los cuatro presidentes EE.UU. tallados en la "montaña de los Seis Abuelos" o el Monte Rushmore en erosionar y tornarse irreconocibles.

${ }^{46}$ Albelda,J; “La naturaleza y su valoración estética contemporánea”. En: http://www.ctfc.es/sipf/docs/albeda7.pdf.
}

confrontación hombre-medio natural que marcaría el desarrollo de algunas propuestas de arte"ecológico", "land art", "earthworks", "landscapes”, etc. según ese exordio, el pensamiento y trato de una naturaleza debilitada ha convertido las intervenciones artísticas de espacios naturales en acciones que vinculan un carácter ético o de respetabilidad que condiciona el valor estético de las mismas. La intervención artística de espacios naturaleses asumida desde un paradigma de corte "ambientalista" y "reclamacionista" como el de la confrontación humana de la Naturaleza, que supone una naturaleza debilitada y conlleva a la norma de respetabilidad.

Evidentemente la respetabilidad prima como norma moral en la intervención artística de espacios naturales reciente, sin embargo ello no implica que las obras mismas no sean pensadas, realizadas, difundidas y criticadas según criterios estéticos. De acuerdo con el nivel de "desarrollo" y las dinámicas de las sociedades industrializadas actuales, el replanteamiento de los esquemas éticos "confrontacionales" con los que se han entendido las relaciones del hombre con la totalidad, no es posible positivamente en ningún otro ámbito que no sea el estético. Así lo entiende Héctor Julio Pérez en su introducción a "La Naturaleza en el arte posmoderno" (2004) pues propone que la Naturaleza debe entenderse, ya no a partir de conceptos como contemplación, expresión o asimilación-conceptos fundamentados en una confrontación humana- sino a partir del concepto de Acción. Pérez señala cómo la Naturaleza es también producto de la Acción humana por lo que la obra de arte de intervención que se vale de un espacio natural, aunque debe asumir un rol que hace posible su apertura no solo desde discusiones con ecos de orden ético (ecologismo, ambientalismo, conservacionismo, etc.), sino estético.

Puede postularse que en la instancia apocalíptica de la construcción de la idea de Naturaleza se da la emergencia de un ideal estético de Redención que influye en la intervención sobre espacios naturales y que se confronta al viejo ideal estético de dominio ${ }^{47}$ propio de las concepciones pródigas. El pensamiento y trato de la Naturaleza en una instancia apocalíptica no implica el estatismo humano, el grado absoluto de respetabilidad, entendido como inalterabilidad del medio natural sino acciones reconciliadoras que equilibren los impulsos órfico-prometeicos. Un ideal es un precepto, una aspiración que encamina la acción humana en un tiempo presente hacia el futuro. El ideal estético es una forma de producción de la realidad en el arte, una re-creación de la Naturaleza. La Redención es puntualmente un ideal como el de la reconciliación ${ }^{48}$, el término tiene un aire teológico cargado de imperativos éticos, imperativos sobre la acción en pro del futuro; redimir es la acción de liberar, de sacrificarse en pos de la vida de otro, de rectificarse y de salir de una situación difícil.

\footnotetext{
${ }^{47}$ Este ideal estético de dominio trabajado por ejemplo por personajes como Adorno en su "teoría estética", donde realiza un estudio sobre la belleza natural y expone que ella aparentemente resultó ser lo doblegado en los conceptos por el ansia de racionalización. Véase el capítulo: "Belleza Natural" Adorno (1983).

${ }^{48}$ La reconciliación señala una síntesis suprema de una relación dialéctica entre hombre y naturaleza que ha sido planteada en otros términos por Marx, Adorno y Susan Buck-Morss.
} 
En la instancia apocalíptica la intervención artística de espacios naturales estaría orientada por el ideal estético de Redención de la Naturaleza, en tanto que este consiste en una búsqueda de relación no instrumental con el medio natural y denotaría una manera de pensar e intervenir la Naturaleza artísticamente acorde a la esperanza de liberarla del yugo humano. No por ello este ideal es meramente funcional y exige la respetabilidad absoluta. Debido al estado de catástrofe natural y la revelación del final de los tiempos, la motivación por modelar, marcar e intervenir un territorio implica acciones que generan una ecúmene de lenguajes artísticos, unas prácticas específicas que buscan ir más allá de cualquier retórica de la catástrofe y valor funcional de la intervención de la Naturaleza: la respetabilidad invoca la conquistabilidad como antítesis, ambos polos como componentes de la intervención artística de espacios naturales actual hacen parte de un impulso redentor o de equilibrio órficoprometeico.

El ideal estético de Redención de la Naturaleza por medio del arte se presenta articulado a sistemas de símbolos: el rito. Un rito funde los límites entre imperativos éticos y planteamientos estéticos, entre preceptos y arte, requiere de conocimientos y prácticas que posibilitan el envío de mensajes que glorifican o piden clemencia a los dioses, garantiza la manutención del orden cósmico en una reunión de acciones con sentido trascendente. De esta forma, ciertas acciones vinculadas a la intervención artística de espacios naturales resultan articulables a un rito, propias de un marco en el que afianzan los preceptos de una fe sin perder su calidad de acciones estéticas emprendidas según cierta poética.

La neo-mitología apocalíptica promueve el ideal de redención y la aparición de rituales para el culto a la Naturaleza con la intención de aplacar sus fuerzas vengativas. El fin del mundo aparece como una posibilidad que pretende aplazarse y evitarse por medio del ritual o mediaciones humanas con la Naturaleza y celebraciones a la misma. De esa manera, los nuevos rituales de expiación, celebraciones pseudoreligiosas reactualizadas a unas reglas del culto a la Naturaleza, conjuran los tópicos escatológicos por medio de actos tendientes a recibir favores divinos o a restituir una relación luego de lo predestinado: algo que no se logra con la mera respetabilidad.

Las intervenciones artísticas de espacios naturales son acciones estéticas que sugieren un deseo de Redención de la Naturaleza, de allí, que muchas de ellas parezcan rituales de restitución o de reconciliación con respecto del accionar del hombre, como lo sugieren algunas prácticas de la arquitectura del paisaje, la escultura de sitio específico o la modelación del jardín con fines reclamativos. A la larga cadena de afecciones a la Naturaleza asociadas al impulso prometeico-moderno, por ejemplo, a los inesperados efectos de la expansión industrial y urbana, se contraponen como corrección, modificaciones artísticas inteligentes de espacios naturales que favorecen la continuidad y la regeneración de procesos geobiológicos de manera simbiótica con la dinámica de las sociedades.

La intervención artística de espacios naturales, pensada como un acto ritual, remite a símbolos asociados a la esperanza de Redención de la Naturaleza propia de las sociedades industrializadas. Solo de esa forma adquieren carácter estético en las sociedades tecnológicamente avanzadas, acciones que evocan símbolos asociados al mundo primitivo, al paso del tiempo y al carácter efímero de los materiales, a intervenciones mínimas, a la búsqueda de lugares hostiles a la actividad humana, a zonas degradadas, etc. puesto que son acciones que se enmarcan dentro de un ritual de las sociedades que viven la catástrofe. En el ritual de intervención artística de espacios naturales el carácter estético de ciertas obras-acciones emerge gracias a la forma y la disposición de los simbolismos inherentes a las obras, ciertos elementos que evocan la tensión entre la actitud prometeica de Conquista, frente a la actitud órfica de Respeto.

\section{Poética de la intervención de espacios naturales}

El término poética, en el sentido de principios y parámetros que dan cuenta de la conciencia de los efectos extrasensoriales de una obra, no solo de las reglas de la composición de la poesía, sino de la creación y la recepción artística, denotaría el sustento estético de la obra-acción en un contexto en el que resulta pertinente. Bien podría ser un canon para la creación, la comprensión y la crítica en el que se dan remisiones a la reconciliación, la recuperación, el respeto, la restauración y en general, a las acciones que se han entendido como búsqueda de Redención de la Naturaleza. Aquí se considera a la poética como un canon con el que se realizan y entienden ciertas acciones catalogadas de estéticas, un marco que promueve una acción que tiene una zona significante y que resulta entendida dentro de ciertos ritos o dinámicas sociales.

El carácter poético de la intervención artística de espacios naturales predominante dentro de la cosmovisión y los rituales de una sociedad industrializada, estaría sujeto al grado de develamiento de la idea de $\mathrm{Na}$ turaleza y acudiría a distintos símbolos orientados a una zona de significado acorde a las necesidades presentes. Una poética de la intervención artística de espacios naturales, entendida como ritual de redención, toma algunos elementos que remiten a afecciones de la obra-acción en el entorno inmediato, debe evaluar su continuidad, su 
forma, manera de respetar el ecosistema, su uso del espacio, su duración, etc. Esto supone un despliegue de símbolos que evocan la búsqueda de equilibrio como los de Conquistabilidad y Respetabilidad de la Naturaleza, simbolismos cuya zona de significado se asociaría a la esperanza de equilibrio órfico-prometeico.

El siguiente cuadro, que precede a su respectivo glosario, presenta elementos relacionados a simbolismos órfico-prometeicos en tensión, lo que sería un canon propuesto o una tabla elementos de la poética de la intervención de espacios naturales sustentada en los "grados de afección" a los entornos.

Tabla de elementos de una poética de la intervención artística de espacios naturales según sus grados de afección al entorno.

\begin{tabular}{|c|c|c|}
\hline $\begin{array}{l}\text { simbolismo* } \\
\text { elemento }\end{array}$ & Prometeico *:Conquista & Órfico : Respeto \\
\hline$\underline{\text { Continuidad }}$ & Imposición de materiales & Mimesis \\
\hline$\underline{\text { Forma }}$ & Antropomorfismo & Biomorfismo \\
\hline$\underline{\text { Modo }}$ & Antropía & Entropía \\
\hline$\underline{\text { Tékhne }}$ & Industrialismo & Primitivismo \\
\hline$\underline{\text { Espacio }}$ & Megalomanía & Intervención mínima \\
\hline$\underline{\text { Tiempo }}$ & Perdurabilidad & Carácter efímero \\
\hline
\end{tabular}

Continuidad ${ }^{49}$ : para Aristóteles era "lo divisible siempre en partes divisibles" algo con límites idénticos. Es decir, un grado de afección del espacio natural que designa la incorporación en él de materiales del entorno inmediato (mimesis) sin crear una discontinuidad o que incorpora nuevos materiales artificiales o evidentemente ajeno al entorno mismo (imposición de materiales).

Forma ${ }^{50}$ : lo susceptible de guardar contenidos en una figura que puede ser apreciada y captada en tanto sus caracteres visibles o externos. Hace referencia, bien sea a formas humanas, es decir, figuras relativas a cosas representadas por el hombre sin contar con las geoformas del espacio natural (antropomorfismo) o por el contrario ser una pérdida de toda abstracción y figuración y aprovecha las condiciones del lugar (biomorfismo).

Modo: hace referencia a los atributos de la intervención, a la intención. La acción sobre la Naturaleza, viene determinada por la intención de cambiarla, independientemente de los juicios de valor sobre la misma (antropía) o por el contrario con la intención de cambiarla teniendo en cuenta la actividad humana y el desorden y generado de la misma en el espacio natural (entropía); el modo de la obra se refiere al uso del espacio natural, a la consideración o desconsideración de sus procesos naturales, la Antropía a una indiferencia utilitaria y la Entropía a la prolongación del ecosistema.

Tékhne ${ }^{51}$ : tal como lo designara Aristóteles, un saber hacer, que se refiere a la transformación del entorno. Sin embargo ese saber hacer, implica una actitud de develamiento, lo que permite distinguir un saber hacer órfico-primitivo (primitivismo) de un saber hacer prometeico-moderno (industrialismo).
Espacio: si se piensa en el espacio natural como un receptáculo, no como un espacio absoluto, la extensión de los cuerpos en el mismo denota la relación con el espacio que ocupan. En ese sentido, se puede pensar en intervenciones no solo gigantescas sino que juegan con el factor "conmensurabilidad", de intervenciones Megalómanas o de intervenciones mínimas.

Tiempo: si se piensa en los procesos naturales, es decir, en todos los factores asociados a los fenómenos intrínsecos a la Naturaleza que afectan a las obras, la intervención artística de espacios naturales debe acogerse o competir con el desgaste de los materiales. En ese sentido, se puede pensar en intervenciones que se valen de los fenómenos naturales (carácter efímero) y lo temporal o intervenciones que buscan o la perdurabilidad (perdurabilidad).

Una poética de la intervención de espacios naturales centrada en la esperanza de Redención determina que las acciones correspondan por medio de sus elementos, al marco de producción simbólica de las sociedades industrializadas. No resulta extraño notar, por medio del señalamiento de elementos inherentes a las obras, que ellas remiten a una búsqueda de equilibrio órfico-prometeico, a grados de afección del entorno según simbolismos en tensión como los de Conquista y Respeto. Por ejemplo, en la creación y la crítica de intervenciones de espacios naturales de artistas relevantes como Christo y Goldsworthy, priman dichos elementos; la crítica y la "producción" de arte de dichos artistas son guiadas por la esperanza de Redención en tanto remiten insistentemente al pensamiento de acciones vinculadas a formas de atenuar o limitar el castigo o la catástrofe y a la búsqueda alternativas para el arte y la vida humana compatibles con la continuidad de los procesos de la Naturaleza. Dos acciones artísticas sobreespacios naturales, tanto en Christo como Goldsworthy, presentan los elementos asociados al grado de afección de las obras-acciones o actitudes de Conquista y Respeto.

\footnotetext{
${ }^{49}$ Véase el artículo "Continuidad”. En: A.A.VV; "Diccionario de filosofía”. Ed. Panamericana. Bogotá. 1997.

${ }^{50}$ Véase el artículo "Forma”; Ibíd.

${ }^{51}$ Véase el artículo "Técnica”; Ibíd.
} 


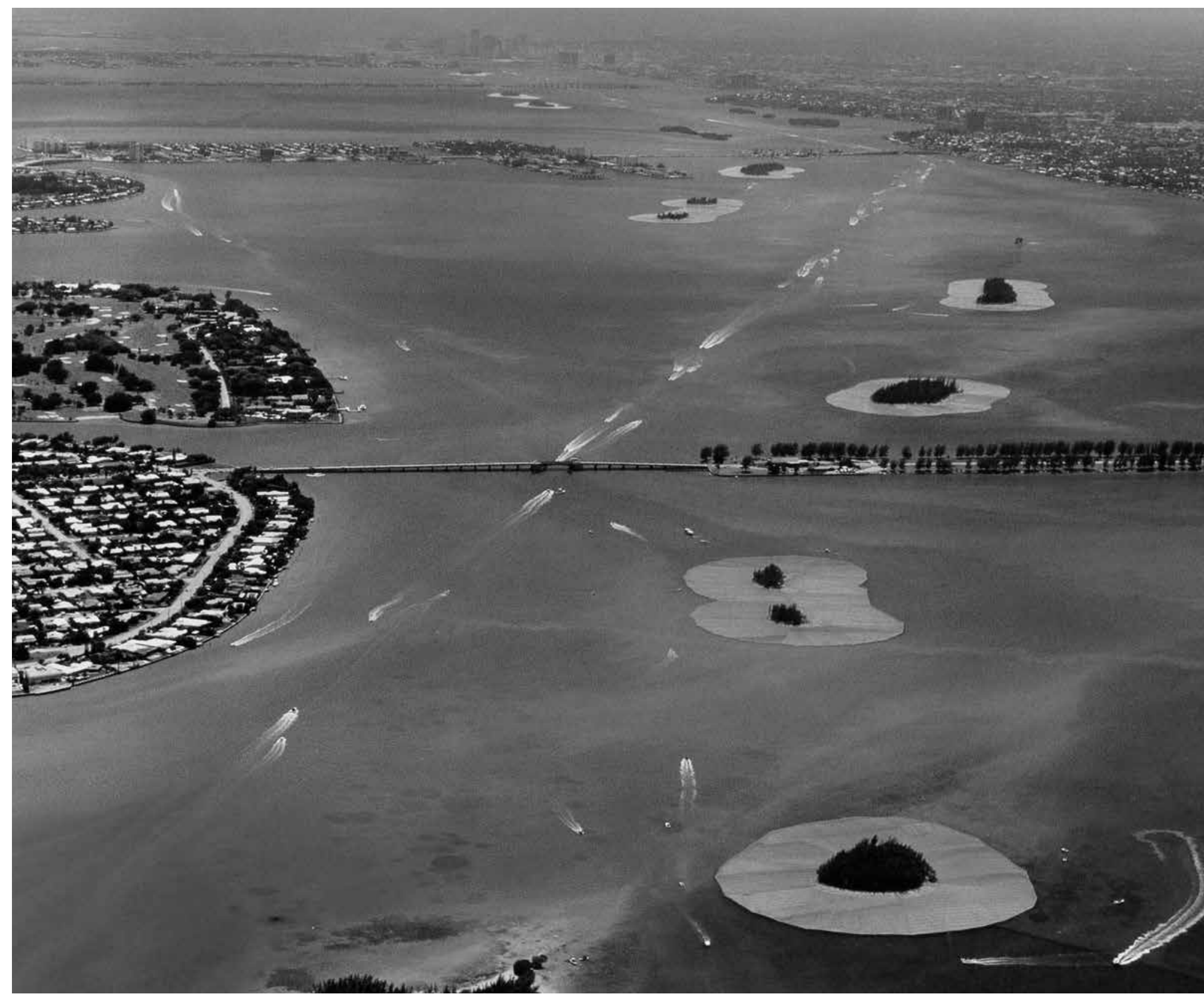

Figura 9. Christo1980/83. "SurroundedIslands".

En "Surroundedislands" (fig. 9) Christo rodeó con cientos de metros de tela color rosa, unos islotes inmensos en Miami. Una acción soberbia y chocante para muchos, o todo lo contrario, si se tiene en cuenta que el artista pensaba los efectos de semejante instalación pues la tela era biodegradable y al parecer se pretendían preservar los factores geobiológicos del sitio de emplazamiento y las condiciones originales del mismo. Christo realizó una acción prometeica, ostentosa, no efímera en sentido estricto, que sin embargo, pretendía afectar al mínimo el espacio natural. A groso modo, siguiendo la tabla anteriormente propuesta se pueden ver en la intervención de Christo elementos asociados a simbolismos de Conquista: en lo relativo al manejo del Espacio es evidente su megalomanía, en la Tékhne la alusión al industrialismo frente a todo primitivismo, en lo referido a la Continuidad se nota la imposición de materiales frente a la mimesis de los mismos con el entorno, en el Tiempo se preeminencia la perdurabilidad de la obra frente al carácter efímero. Sin embargo puede notarse algo de actitud órfica o de respeto por el espacio natural, por ejemplo, su Modo es entrópico pues pretende una continuidad del ecosistema y su Forma es biomorfica en tanto aprovecha las condiciones iníciales del lugar. 


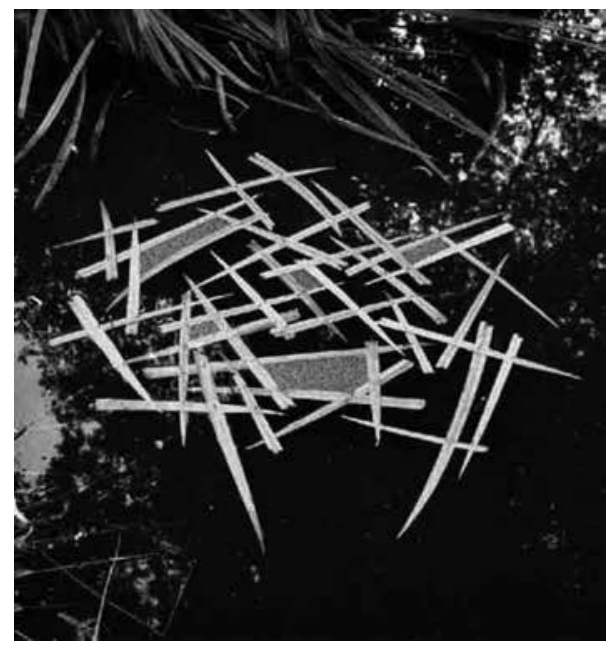

Fig. 10. Andy Goldsworthy. 1989. Iris Leaves with Rowan Berries

Por su parte, Goldsworthy, preeminencia la conciencia de cambio y transformación del medio, el clima, la inestabilidad; realiza una obraacción, cuyo título son los materiales -algo así como Iris de hojas con bayas enfiladas caracterizada por la manipulación de materiales, hojas, flores, agua, un emplazamiento cuyo resultado es una escultura integrada en un espacio natural y cuya perdurabilidad está determinada por el paso del tiempo y los fenómenos climáticos. La prometeización de esta obra, muchísimo menor que la de Christo, se delimita a una mínima y pasajera perdida de Continuidad, una ínfima imposición de materiales al entorno, presenta en cambio, una aguda actitud órfica del artista; la Tékhne denota cierto primitivismo, la Forma sugiere cierto grado de biomorfismo, tiene un Modo entrópico pues acude a una prolongación del ecosistema, en lo referido al Tiempo presenta un carácter efímero y al Espacio una intervención mínima. Haciendo énfasis en el respeto se nota cómo el grado de afección resulta un factor importante en esta obra y señala una clara preocupación por conciliar la actividad artística y el desarrollo de los procesos naturales.

\section{Referencias}

"La Biblia" (1960). Versión casiodoro reina- cipriano valera.

Aa.Vv (1997): diccionario de filosofía.Bogotá: ed. Panamericana.

Adorno, T. W (1983). Teoría estética. Madrid: ed. Orbis.

Albelda, J; Saborit, J. (1997). La construcción de la naturaleza. Valencia:

Ed. Generalitat valenciana.

Albers, P. C. De Mallie (2001). Handbook of north american indians. Washington, D.C: volumen 13, parte 2. Smithsonian inst.

Arnold, D. (2000). La naturaleza como problema histórico: el medio, la cultura, la expansión de europa. México: Ed. Fondo de Cultura Económica. Buck-morss, S. (2004). Mundo soñado y catástrofe: la desaparición de la utopía de las masas de este y el oeste. Madrid: Machado Lbros.

Danto, A. (2005): The american sublime. En: El Diario "thenation”. Edición del día 19 de septiembre de 2005. Http://www.Thenation.Com/ doc/20050919/danto

Dieges, A. (2005). El mito moderno de la naturaleza intocada. Sao Paulo: nupaub.

Galofaro, L. (2003). El arte como aproximación al paisaje contemporáneo. Barcelona: Ed. Gili.

Geyer, C. (1985). Teoria critica: max horkheimer, T.W Adorno. Barcelona: alfa.

Hadot, P. (2004). Le voiled isis: essai sur l’histoire de l’ideé de nature. París: Gallimard.

Horkheimer, M; Adorno, T. (1994). Dialéctica de la ilustración. Madrid: Ed. Trotta.

Jones, C. (1998). Machine in the studio: constructing the postwar american artist. Chicago: Chicago University Press.

Julio, P, H. (2004). La naturaleza en el arte posmoderno. Madrid: Akal.

Laurie, M. (1983). Introducción a la arquitectura del paisaje. Barcelona: Ed. Gustavo Gili.

Lévi-strauss, C. (2002). El pensamiento salvaje. México: Fondo de Cultura Económica.

Morin, E. (1986). El método. El conocimiento del conocimiento. Madrid: tomo 3. Edit. Cátedra.

Mottet, J. (2006). Análisis de una manera de domesticar la naturaleza: la casa en la hierba de las series americanas. En: Salabert, Parret, Chateau (2006): Estética plural de la naturaleza. Barcelona: ed. Laertes.

Rodríguez, P; Lanzetti, R. (1982). El catecismo romano. Fuentes e historia del texto y de la redacción. Bases críticas para el estudio teológico del catecismo del concilio de trento (1566). Pamplona: Universidad de Pamplona.

Salabert, P. (2006). El mundo en un cuadro de familia. En: Salabert, Parret, Chateau. (2006): Estética plural de la naturaleza. Barcelona: Ed. Laertes.

Taylor, M, C. (1991). Michael heizer: double negative sculpture in the land. Nevada: Museum of Contemporary Art New York, Institute for Contemporary Art at the University of Nevada. Las vegas.

Vínculos web

- Parque Natural Yosemite http://www.nps.gov/Yose/index.htm

- Crazy Horse Memorial http://www.crazyhorsememorial.org/

- Mount Rushmore National Memorial: http://www.nps.gov/moru/ index.htm.

http://waste.ideal.es/sealth.htm.

- Carta del jefe Noah sealth: Murray Morgan, Skid Road, 1951, ISBN 0-295-95846-4

- "Chief Seattle" en: www.wikipedia.com.

- Noah Sealth Seattle: http://www.atinachile.cl/node/2250

- Albelda, J; "La naturaleza y su valoración estética contemporánea". En: http://www.ctfc.es/sipf/docs/albeda7.pdf. 
Índice de imágenes

- Fig. 1. Albert Bierstadt. "IndianEncampment Yosemite Valley". (1872). tomado de http://www.albertbierstadt.org/

- Fig.2. GutzonBorglum. (1927- 1941), "RushmoreNational Memorial”. Tomada de: http://www.mtrushmorenationalmemorial.com/ gallery/

- Fig. 3. GutzonBorglum. (1927- 1941), "Rushmore National Memorial". Tomada de: http://www.mtrushmorenationalmemorial.com/ gallery/

- Fig.4. "The Six Grandfathers" en 1905. La imagen se denomina "Mount Rushmore before work began for the four faces". Extraído de la página de la organización de viajeros de parques nacionales http:// www.nationalparkstraveler.com/files/storyphotos/Mount-rushmorebefore-carvi.jpg

- Fig.5. Michael Heizer, "Double Negative” Overton, Nevada. (1969. 70). Vista desde el interior de una de las zanjas. Extraída de la página de la obra. En: http://doublenegative.tarasen.net/

- Fig.6. Michael Heizer, "DoubleNegative" Overton, Nevada (1969. 1970)desde el espacio a través de satélite, extraída de la página de la obra. En : http://doublenegative.tarasen.net/

- Fig.7. Mark Tansey. "Purity Test". (1982). Extraída de: http:www. hawaii.edu/lruby/art302/PURITY.GIF

- Fig. 8. Matthew Buckingham, "The Six Grandfathers, PahaSapa, in the Year 502,002 C.E.”. (2002). Acompañada de textos de Buckingham con la historia "velada" del monte Rushmore. Publicado en Cabinet magazine numero 7 verano del 2002.http://www.cabinetmagazine. org/issues/7/assets/images/main/6grandfathers.jpg

- Fig. 9. Christo. "Surrounded Islands". (1980-1983). Miami, Florida. Extraída de: http://www.easyart.com/art-prints/Christo/SurroundedIslands,-Biscayne-Bay,-Miami-166529.html Miami. 1980/83.

- Fig. 10. Andy Goldsworthy."Iris Leaves with Rowan Berries”. (1989). http://jjoartapp.wordpress.com/

\section{Javier Guillermo Merchán-Basabe}

merchanbasabe@gmail.com

Filósofo y Mg. en Historia y Teoría del Arte y la Arquitectura. Docente Universitario de la Universidad Pedagógica Nacional en la Licenciatura de Artes Visuales. Investigador en el área de las relaciones Arte y Naturaleza y de la Estética medioambiental inscrito en CVLAC. Músico y artista independiente.

Artículo recibido en marzo de 2011 y aceptado agosto de 2011. 